\title{
The spider genus Pirata Sundevall, 1833 (Aranei: Lycosidae) in Crimea and Abkhazia
}

\author{
Пауки рода Pirata Sundevall, 1833 (Aranei: Lycosidae) \\ Крыма и Абхазии
}

\author{
Anton A. Nadolny, Mykola M. Kovblyuk \\ А.А. Надольный, Н.М. Ковблюк \\ Zoology Department, V.I. Vernadsky Taurida National University, Yaltinskaya Str. 4, Simferopol 95007, Ukraine. E-mail: \\ nadolnyanton@mail.ru; kovblyuk@mail.ru \\ Кафедра зоологии Таврического национального университета им. В.И.Вернадского, ул. Ялтинская 4, Симферополь 95007, Украина.
}

KEY WORDS: spiders, Pirata, redescriptions, fertility, Crimea, Abkhazia.

КЛЮЧЕВЫЕ СЛОВА: пауки, Pirata, переописания, плодовитость, Крым, Абхазия.

ABSTRACT. Illustrated redescriptions are provided for 5 species of the genus Pirata Sundevall, 1833, of specimens from Crimea and Abkhazia: P. hurkai Buchar, 1966; P. hygrophilus Thorell, 1872; P. latitans (Blackwall, 1841); P. piraticus (Clerck, 1757) and $P$. tenuitarsis Simon, 1876. Illustrations of $P$. knorri (Scopoli, 1763) and $P$. piraticus from Bulgaria are presented for comparison with Crimean species. $P$. latitans and $P$. piraticus are recorded from Abkhazia for the first time. Data on the variation of body size, copulatory organs structure and fertility of studied species are provided.

РЕЗЮМЕ. По экземплярам из Крыма и Абхазии даны иллюстрированные переописания 5 видов рода Pirata: P. hurkai Buchar, 1966; P. hygrophilus Thorell, 1872; P. latitans (Blackwall, 1841); P. piraticus (Cler$\mathrm{ck}, 1757)$ и $P$. tenuitarsis Simon, 1876. Для сравнения даны рисунки $P$. knorri (Scopoli, 1763) и P. piraticus из Болгарии. $P$. latitans и $P$. piraticus впервые отмечены для Абхазии. Приведены сведения по изменчивости изученных видов в размерах, деталях строения копулятивных органов и в плодовитости.

\section{Introduction}

The genus Pirata contains 91 described species worldwide (except Australia and New Zealand) [Platnick, 2010]. The type species of the genus is Araneus piraticus Clerck, 1757. Eight species of Pirata are known from Central Europe [Heimer \& Nentwig, 1991], 15 species are reported the former USSR [Mikhailov, 1997] and nine species are reported from Ukraine: $P$. cereipes (C.L. Koch, 1878), P. hurkai, P. hygrophilus, $P$. knorri, P. latitans, $P$. piraticus, $P$. piscatorius (Clerck, 1757), P. tenuitarsis and P. uliginosus (Thorell, 1856) [Mikhailov, 1997, 1998; Kovblyuk, 2004a, 2007;
Polchaninova \& Prokopenko, 2007]. However, accurate record lists eight Ukrainian species only, because of the erroneous record of $P$. cereipes, which was the misidentification of Evippa apsheronica Marusik, Guseinov et Koponen, 2003 [Ponomarev, personal communication]. Four species of Pirata were recorded from Crimea: $P$. hurkai, $P$. latitans, $P$. piraticus and $P$. tenuitarsis [Spassky, 1927; Charitonov, 1932; Mikhailov, 1997; Kovblyuk, 2004a, 2007]. Seven species were reported from Caucasus: P. hurkai, P. hygrophilus, P. insularis Emerton, 1885, P. knorri, P. latitans, P. piraticus, P. piscatorius [Ovtsharenko, 1979; Mikhailov, 1997, 1998; Guseinov, 1999; Marusik et al., 2003; Ponomarev, Mikhailov, 2007; Ponomarev et al., 2008; Kovblyuk et al., 2011]. Thus, Pirata species in Crimea and Caucasus are studied more or less completely.

Structures of copulatory organs in Pirata species are poorly known. Except some works [Kronestedt, 1980], most authors made schematic drawings of bulbus and epigyne, without details of their structure. For many Pirata species (for example: P. hurkai and $P$. latitans) embolar part of bulbus has been never studied and illustrated.

The goal of this paper is detailed re-descripition and illustration of copulatory organs of Pirata species known from Crimea and Abkhazia, and to provide information about new records and variations of body size, copulatory organs and fertility for each species.

\section{Material and Methods}

Specimens for this study were collected in Crimea (during 2000-2008) and Abkhazia (July 2008 and JulyAugust 2009). Specimens of P. knorri and P. piraticus from Bulgaria (courtesy of Dr Christo Deltshev) were used as comparative material. 


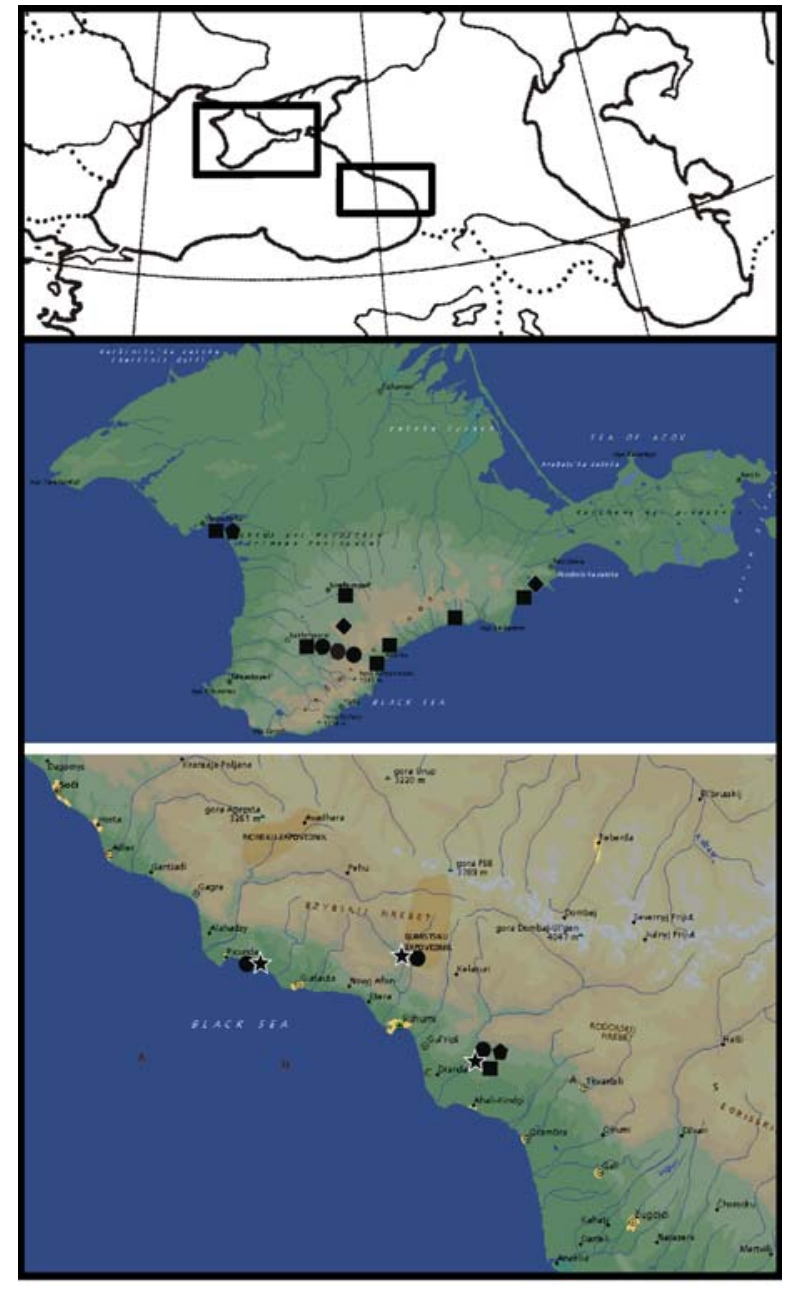

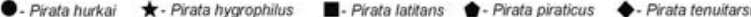

Map 1. Study area in Crimea and Abkhazia.

Карта 1. Район исследований.

The collectors' names are abbreviated as follows: A.N. - A.A. Nadolny; E.S. - E.Yu. Sviridenko; G.P. - G.A. Prokopov; M.K. - M.M. Kovblyuk; O.K. - O.V. Kukushkin. All specimens are deposited to Zoology Department, V.I. Vernadsky Taurida National University, Simferopol, Ukraine, curator of collection M.M. Kovblyuk (TNU) and Institute of Zoology in Sofia, Bulgaria, curator of collection Ch. Deltshev (IZS).

Abbreviations used in the text: a - apical; $d$ dorsal; pl — prolateral; rl — retrolateral; v — ventral.

Terms and abbreviations for genital descriptions are adopted from T. Kronestedt [1980], H. Tanaka [1986, 1988] and D. Logunov [1998]. Definitions of development stages are adopted from M. Downes [1987]. Abbreviations on figures: $b h$ - basal haematodocha; co - copulatory opening; $d h$ - distal haematodocha; $e$ - embolus; $f d$ - fertility duct; re receptacles (spermathecal reservoirs); $s$ - epigynal septum; sh - shell; st - subtegulum; $t g$ - tegulum; tg.ap — tegular apophysis; tl.ap — terminal apophysis; $t l . p t$ - terminal part of bulbus.
Illustrations were made using reflecting and transmitted light microscopes. Illustrations of epigynes were made after maceration in $\mathrm{KOH} 20 \%$ water solution. Coloration was described from specimens preserved in $75 \%$ ethanol/water solution with added glycerin $(9: 1$ by volume). Legs and palpal segments were measured after their separation from the cephalothorax. All measurements are in $\mathrm{mm}$. All scale bars are equal $0.1 \mathrm{~mm}$.

\section{Survey of species}

Pirata hurkai Buchar, 1966

Figs 1, 6, 10, 16-31, 35-53.

P. h. Buchar, 1966: 210-213, f. 1A-B, E-F, 2A, 4E ( ( $\left.^{7}\right)$.

P. h.: Ovtsharenko, 1979: 40, f. 33 ( $\left.\mathrm{O}^{7}\right)$.

P. h.: Mcheidze, 1997: 244, f. 529-530 ( $\sigma^{7}$; figs are taken from Buchar [1966]).

RECORDS FROM CRIMEA. Kovblyuk [2002, 2004ab]

RECORDS FROM ABKHAZIA. Buchar [1966]; Kovblyuk et al. [2011].

MATERIAL. UKRAINE, CRIMEA. Bakhchisaray Distr.: Crimean State Nature Reserve: $6 \sigma^{7} \sigma^{7}, 1$ q (TNU-1038/1), kordon Tarier, bank of Alma River, 30.06.2001, M.K.; 1 ㅇ (TNU-1041/3), kordon Sosnovyi, 1.07.2001, M.K.; 13 우, 13 cocoons (TNU1204/4), 1,5 km NW kordon Asport, Alma River bank, 21.08.2001, M.K. ABKHAZIA. Gudauta Distr.: $12 \sigma^{7} \sigma^{7}, 33$ 오, 7 cocoons

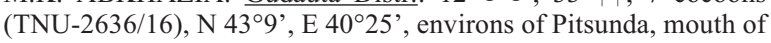
Ryapsh River, Myusser Distr. of Pitsundo-Myusser Reserve, wood with Arbutus, Alnus, Ficus, Carpinus, Quercus, Acer, Rhododendron, Erica arborea, Rubus, Smilax excelsa, Castanea sativa, Laurocerasus officinalis, Cornus mas, Pinus pithyusa, Crataegus,

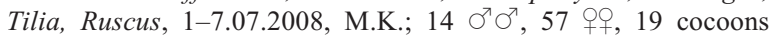
(TNU-2651/65), N 4310', E 40²5', 23 m, environs of Pitsunda, Myusser Distr. of Pitsundo-Myusser Reserve, left bank of Ryapsh River, wood with Arbutus, Alnus, Ficus, Carpinus, Quercus, Acer, Rhododendron, Erica arborea, Rubus, Smilax excelsa, Castanea sativa, Laurocerasus officinalis, Cornus mas, Pinus pithyusa, Crataegus, Tilia, Ruscus, 15-24.07.2009, M.K.; Sukhum Distr.: 3

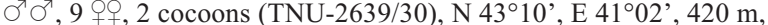
Gumysta Reserve, East Gumysta River, kordon Tsymur, 810.07.2008, M.K.; Ochamchyra Distr.: 8 우 (TNU-2653/55/3), N $42^{\circ} 53^{\prime}-57^{\prime}$, E $41^{\circ} 17^{\prime}-19^{\prime}, 141-253 \mathrm{~m}$, environs of Atara-Armyanskaya Vill. and Naa Vill., left bank of Kodor River, foot of Kodor Mt. ridge, wood with Alnus, Quercus, Fagus, Carpinus, Aesculus, Corylus, Tilia and Rhododendron, glades, 24.07-04.08.2009, M.K.

COMPARATIVE MATERIAL. Pirata knorri (Scopoli, 1763) from BULGARIA, $10^{\pi}, 2$, (IZS), Zemen Gorge, Ruzhdatvitsa Vill., 05.06.1984, G. Blagoev. Drawings from Bulgarian specimens - see in Figs 2, 11, 32-34, 79-82.

DIAGNOSIS. P. hurkai is similar to P. knorri and $P$. latitans. Males are distinguished by the shape of tegular apophysis. Retrolaterally directed lobe of tegular apophysis in $P$. hurkai (Figs 1, 18) is narrower than in P. knorri (Figs 2, 80) and P. latitans (Figs 3, 84). The tegulum of each of these species has a tooth; however, the drawing of $P$. knorri in Tanaka [1988: $\mathrm{f}$. 46] depicts the tegulum without tooth. P. hurkai males have a number of thick thorns located retrolaterally on palpal tibiae (Fig. 6), but these are absent in P. knorri and $P$. latitans. Females of $P$. latitans (Figs 12, 90-93) can be easily distinguished from $P$. hurkai (Figs 10, 29-31) and P. knorri (Figs 11, 32-34) by the spherical shape of receptacles. Epigynes of $P$. hurkai and $P$. knorri are very similar and difficult to distinguish (they differ in shape of receptacles). 


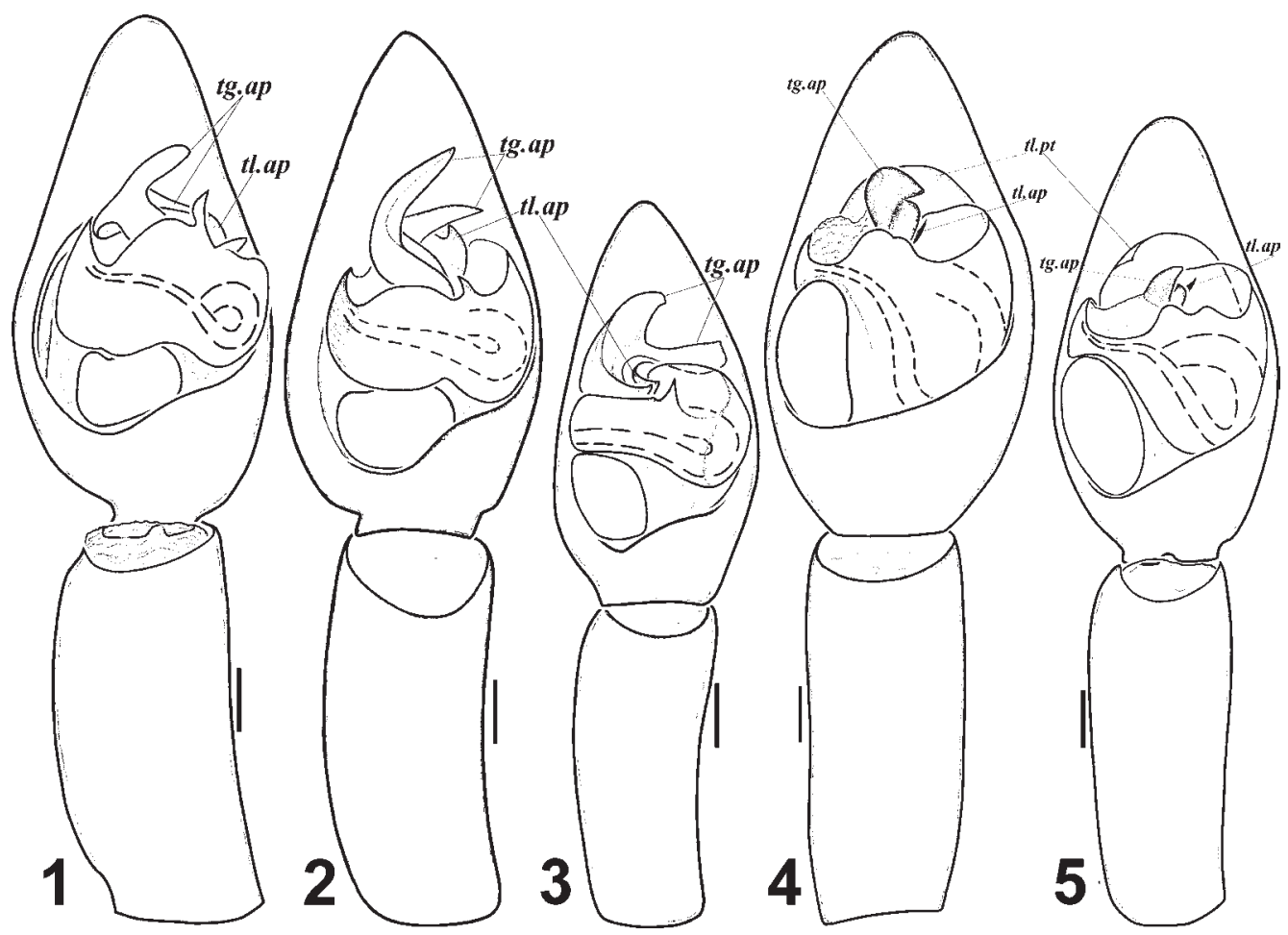

Figs 1-5. Male palp of Pirata hurkai (1), P. knorri (2), P. latitans (3), P. piraticus (4) and P. tenuitarsis (5), ventral view. 1, 3, 5 from Crimea; 2, 4 - from Bulgaria.

Рис. 1-5. Пальпы самцов Pirata hurkai (1), P. knorri (2), P. latitans (3), P. piraticus (4) и P. tenuitarsis (5), вентрально. 1, 3, 5 из Крыма; 2, 4 - из Болгарии.

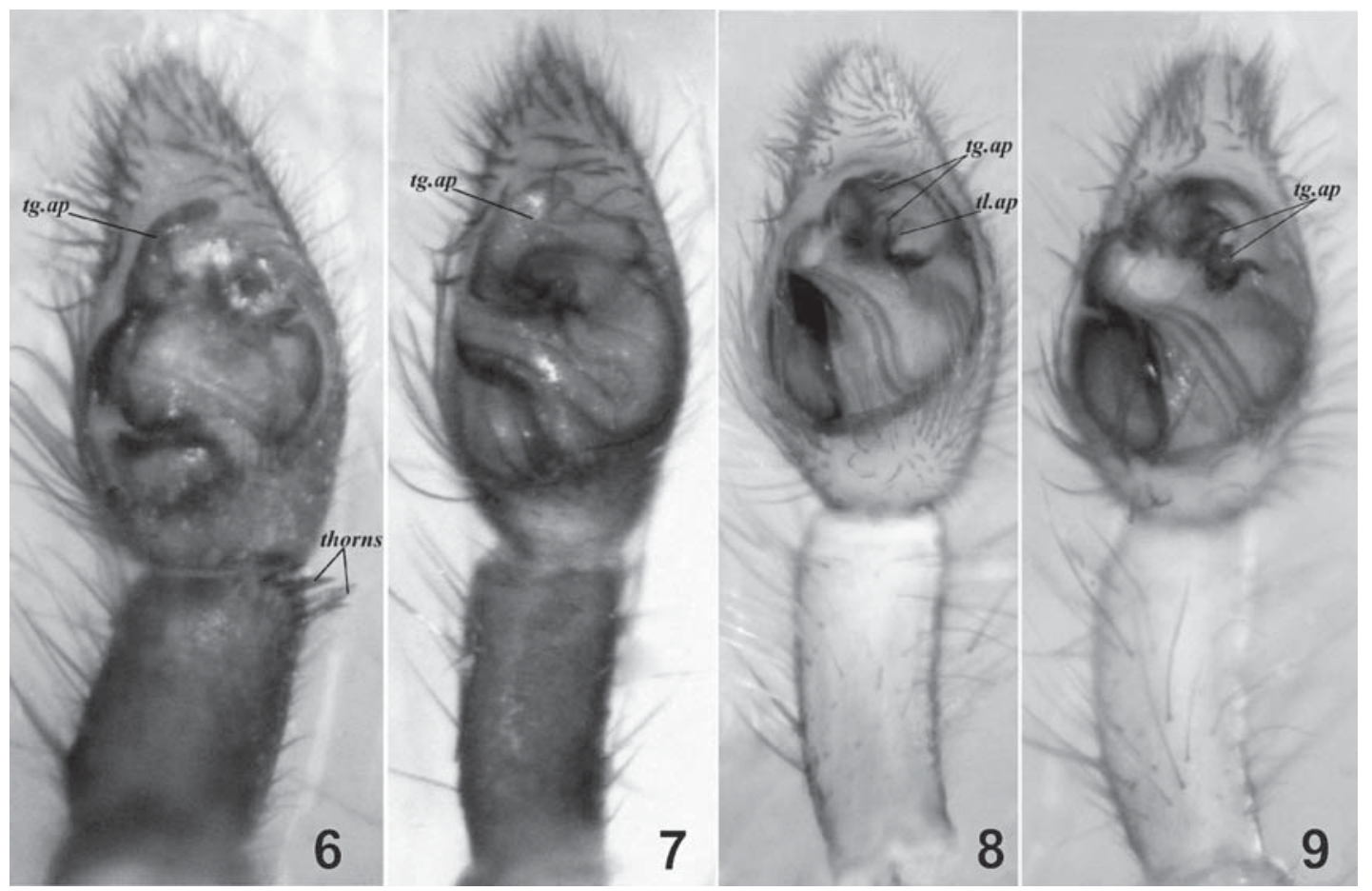

Figs 6-9. Male palp of Pirata hurkai (6, from Abkhazia), P. latitans (7, from Crimea), P. piraticus (8, from Bulgaria) and $P$. tenuitarsis (9, from Crimea), ventral view.

Pис. 6-9. Пальпы самцов Pirata hurkai (6, из Абхазии), P. latitans (7, из Крыма), P. piraticus (8, из Болгарии) и P. tenuitarsis $(9$, из Крыма), вентрально. 

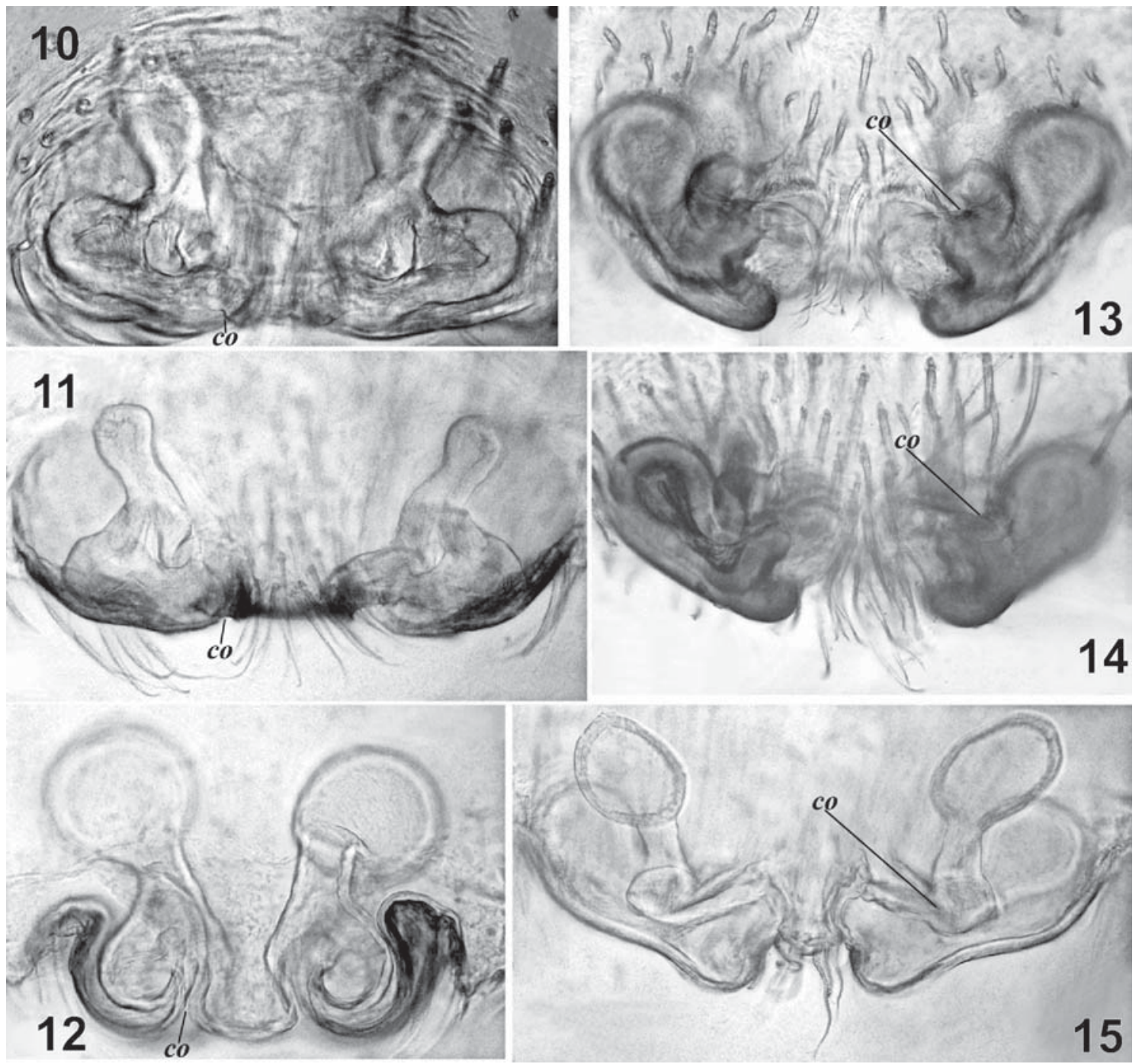

Figs 10-15. Epigynes of Pirata hurkai (10, from Crimea), P. knorri (11, from Bulgaria), P. latitans (12, from Crimea), P. piraticus (13 - from Bulgaria, 14 - from Crimea) and P. tenuitarsis (15, from Crimea): 10-11, 13-15 - ventral view; 12 - dorsal view.

Рис. 10-15. Эпигины Pirata hurkai (10, из Крыма), P. knorri (11, из Болгарии), P. latitans (12, из Крыма), P. piraticus (13 - из Болгарии, 14 - из Крыма) и $P$. tenuitarsis (15, из Крыма): 10-11, 13-15 - вентрально; 12 - дорсально.

DESCRIPTION. Male and female from Crimea. Measurements $\left(\sigma^{7} / q\right)$ : total length 4.8 / 5.4; carapace 2.6 / 2.8 long, 1.9 / 2 .1 wide. Length of palp segments (male/female): femur $1.0 / 1.0$, patella $0.5 / 0.5$, tibia 0.5 / 0.6, tarsus $0.8 / 0.8$. Length of leg segments (male/ female):

\begin{tabular}{|c|c|c|c|c|c|c|}
\hline Leg & Femur & Patella & Tibia & Metatarsus & Tarsus & Total \\
\hline I & $2.0 / 2.2$ & $1.0 / 1.0$ & $1.6 / 1.7$ & $1.7 / 1.8$ & $0.9 / 0.9$ & $7.2 / 7.6$ \\
\hline II & $2.0 / 2.1$ & $1.0 / 1.0$ & $1.5 / 1.6$ & $1.9 / 1.8$ & $0.9 / 0.8$ & $7.3 / 7.3$ \\
\hline III & $1.9 / 2.0$ & $0.8 / 1.0$ & $1.4 / 1.4$ & $1.9 / 1.9$ & $0.8 / 0.8$ & $6.8 / 7.1$ \\
\hline IV & $2.5 / 2.9$ & $1.0 / 1.1$ & $2.0 / 2.2$ & $2.8 / 2.9$ & $1.0 / 1.1$ & $9.3 / 10.2$ \\
\hline
\end{tabular}

General appearance: male — Figs 35-39; female -

Figs 41-46. Carapace, sternum, legs and palps brown. Sternum with light stain.

Male palp as in Figs 1, 6, 16-28, 40 and epigyne as in Figs 10, 29-31. Ventral part of the tegular apophysis is hidden behind the tegulum (Figs 1, 20). Terminal apophysis is visible only from dorsal view (Fig. 18). Terminal apophysis has two lobes. Ventrally directed lobe can be with or without a tooth (Figs 25-28). Males have a number of thick thorns located retrolaterally on palpal tibia (Fig. 6).

VARIATION. Males from Crimea $(n=6)$ : total length varies from 4.8 to 5.6; carapace length - from 2.6 to 3.0, carapace width - from 1.9 to 2.1. Males from Abkhazia $(n=12)$ : total length varies from 3.8 to 4.7 ; carapace length - from 2.1 to 2.6, carapace width from 1.4 to 1.8 . Females from Crimea $(n=14)$ : total length varies from 4.5 to 5.6; carapace length - from 2.4 to 3.1 , carapace width - from 1.6 to 2.5 . Females from Abkhazia $(n=12)$ : total length varies from 4.6 to 6.4; carapace length 2.4-2.8, carapace width 1.7-2.0. 

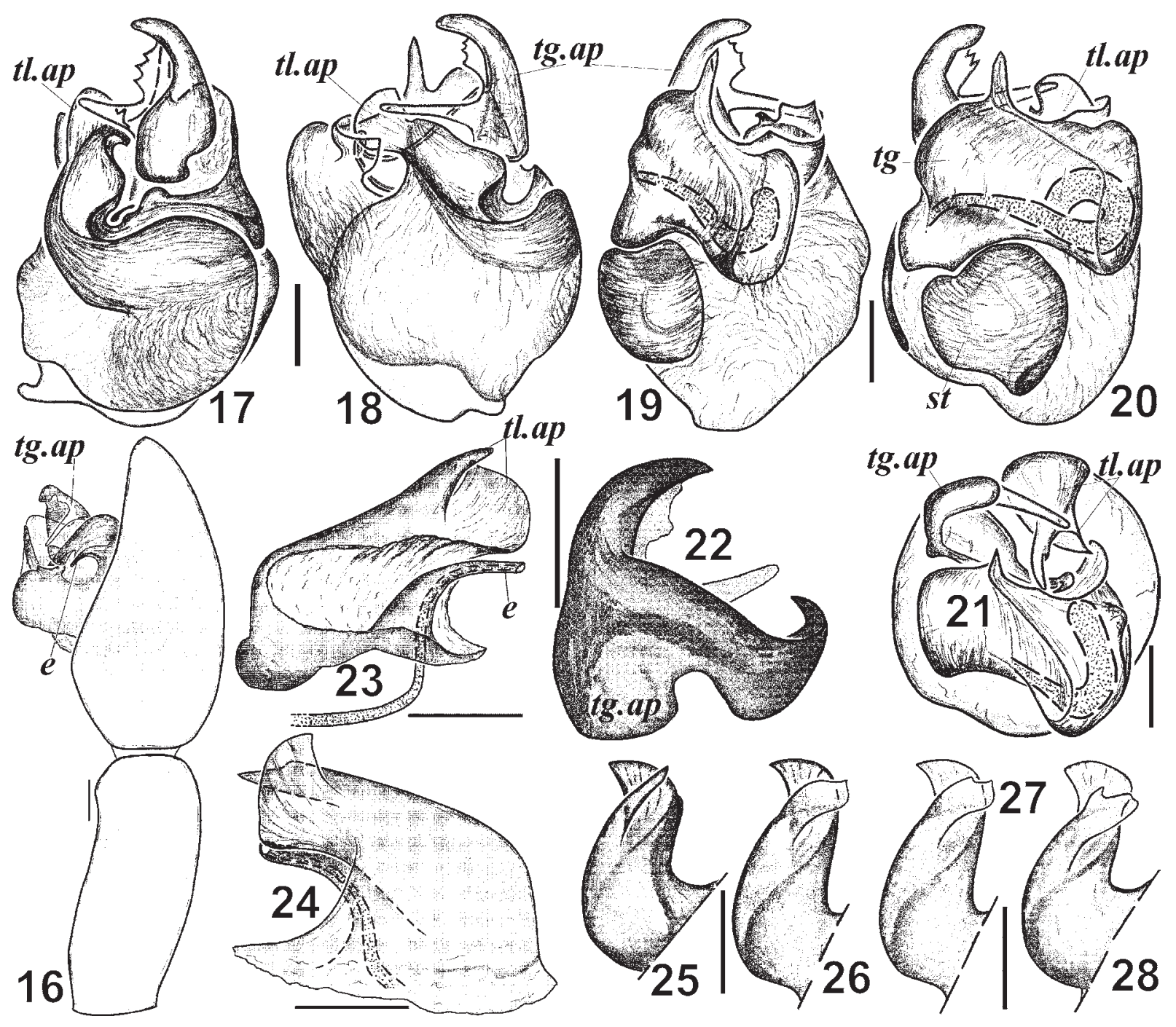

Figs 16-28. Male palp of Pirata hurkai (16-21, 23-24, 27-28 - from Crimea, 22, 25-26 - from Abkhazia): 16 - partly expanded male palp, retrolateral view; 17 - bulbus, prolateral view; 18 - bulbus, dorsal view; 19 - bulbus, retrolateral view; 20 - bulbus, ventral view; 21 - bulbus, apical view; 22 - tegular apophysis, ventral view; 23 - embolus and terminal apophysis, ventral view; 24 embolus and terminal apophysis, dorsal view; $25-28$ - variation of terminal apophysis, ventral view.

Рис. 16-28. Пальпа самца Pirata hurkai (16-21, 23-24, 27-28 - из Крыма, 22, 25-26 — из Абхазии): 16 — пальпа с вывернутым бульбусом, ретролатерально; 17 - бульбус, пролатерально; 18 - бульбус, дорсально; 19 - бульбус, ретролатерально; 20 - бульбус, вентрально; 21 - бульбус, апикально; 22 - тегулярный апофиз, вентрально; 23 - эмболюс и терминальный апофиз, вентрально; 24 - эмболюс и терминальный апофиз, дорсально; 25-28 - изменчивость формы терминального апофиза, вид вентрально.

COCOONS AND FERTILITY. Females with cocoons were taken in Crimea in August (13 females with 13 cocoons). Diameter of cocoons $(n=13)$ varies from 2.7 to 3.8 , height — from 1.8 to 3.2 . Nine cocoons were with eggs, four cocoons with nymphs at the different development stages (with pigment in eyes plate or without it - Figs 50-52). Number of eggs in cocoons were from 9 to 30 , number of nymphs - from 22 to 31. Diameter of eggs $0.8-0.9$. Total length of nymphs 1.2-1.3. Cocoons, eggs and nymphs see on Figs 47-53.
Females with cocoons were obtained in Abkhazia in July (107 females with 28 cocoons). Diameter of cocoons $(n=9)$ varies from 3.0 to 3.7 , height - from 2.7 to 3.0. Three cocoons had eggs, six cocoons were with nymphs at the different development stages. Number of eggs in cocoons - from 41 to 45 , number of nymphs - from 31 to 43 . Diameter of eggs 0.8 . Total length of nymphs $1.0-1.1$.

DISTRIBUTION. P. hurkai is known only from Crimean Mountains and West Caucasus: Ukraine (Crimea), Russia (Krasnodar Area - Caucasian Re- 


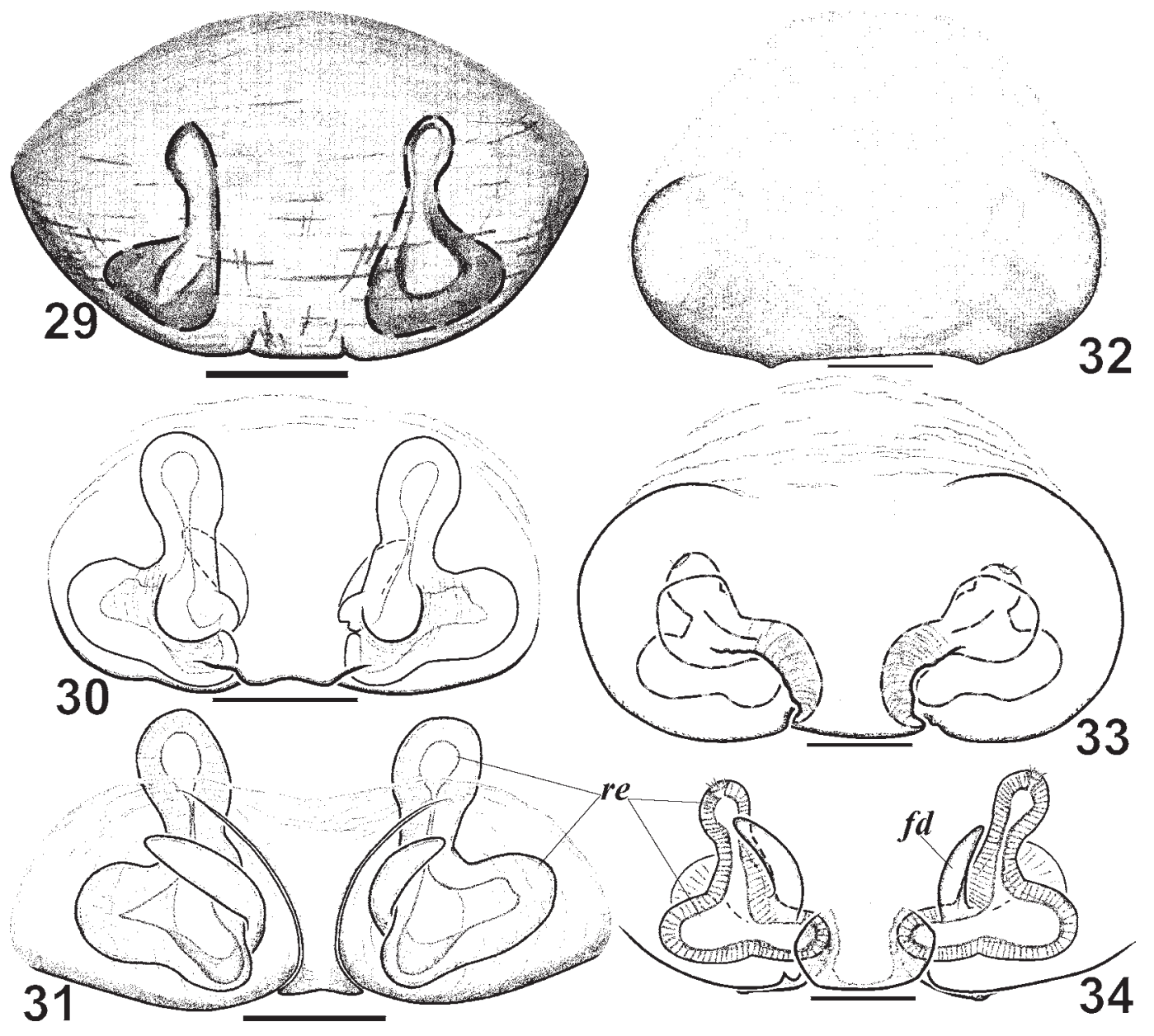

Figs 29-34. Epigynes of Pirata hurkai (29-31, from Crimea) and P. knorri (32-34, from Bulgaria): 29, 32 — ventral view; 30, 33 ventral view; 31,34 - dorsal view.

Рис. 29-34. Эпигины Pirata hurkai (29-31, из Крыма) и P. knorri (32-34, из Болгарии): 29, 32 - вентрально; 30, 33 вентрально (после мацерации); 31, 34 - дорсально (после мацерации).

serve; Krasnaya Polyana), Abkhazia, Georgia [Buchar, 1966; Ovtsharenko, 1979; Mcheidze, 1997; Kovblyuk, 2004a; Kovblyuk et al., 2011]. Crimea is the most western part of its range.

Pirata hygrophilus Thorell, 1872

Figs 54-78.

P. h.: Kronestedt, 1980: 65, f. 9E-F, 10B $\left(0^{7}\right)$.

P. h.: Roberts, 1995: 233, f. (O'T).

For a complete list of references see Platnick [2010].

RECORDS FROM ABKHAZIA. Kovblyuk et al. [2011].

MATERIAL. ABKHAZIA. Gudauta Distr.: 3 우 (TNU-2636/ 15), N 439', E $40^{\circ} 25^{\prime}$, environs of Pitsunda, Myusser Distr. of Pitsundo-Myusser Reserve, mouth of Ryapsh River, wood with Arbutus, Alnus, Ficus, Carpinus, Quercus, Acer, Rhododendron, Erica arborea, Rubus, Smilax excelsa, Castanea sativa, Laurocerasus officinalis, Cornus mas, Pinus pithyusa, Crataegus, Tilia, Ruscus, 1-7.07.2008, M.K.; Sukhum Distr.: $10^{7}, 7$ 우 (TNU-

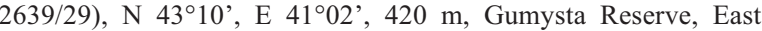
Gumysta River, kordon Tsymur, 8-10.07.2008, M.K.; Ochamchyra Distr.: 9 우, 1 cocoon (TNU-2653/54), N 4253'-57', E $41^{\circ} 17^{\prime}-19^{\prime}, 141-253 \mathrm{~m}$, environs of Atara-Armyanskaya Vill. and
Naa Vill., left bank of Kodor River, bottom of Kodor Mt. ridge, wood with Alnus, Quercus, Fagus, Carpinus, Aesculus, Corylus, Tilia and Rhododendron, glades, 24.07.-04.08.2009, M.K.

DIAGNOSIS. P. hygrophilus is the closest species to $P$. uliginosus and P. hiroshii Tanaka, 1986 from Japan. Males of $P$. hygrophilus are distinguished by the characteristic shape of tegular apophysis and embolar part of bulbus (Figs 55, 57, 59-62, 69-71). Females of P. hygrophilus (Figs 63, 76-77) have narrower epigynal septum than $P$. uliginosus; $P$. hiroshii has no septum in epigyne [Tanaka, 1986: f. 1-4; Tanaka, 1988: f. 41-44].

DESCRIPTION. Measurements $\left(\sigma^{\top} /+\right)$ : total length 4.5 / 5.8; carapace 2.6 / 3.0 long, 1.9 / 2.2 wide. Length of palp segments (male/female): femur $0.8 / 1.0$, patella $0.5 / 0.5$, tibia $0.5 / 0.7$, tarsus $0.9 / 0.9$. Length of leg segments (male/female):

\begin{tabular}{|c|c|c|c|c|c|c|}
\hline Leg & Femur & Patella & Tibia & Metatarsus & Tarsus & Total \\
\hline I & $1.8 / 2.2$ & $0.8 / 1.0$ & $1.4 / 1.7$ & $1.6 / 1.7$ & $0.8 / 0.8$ & $6.4 / 7.4$ \\
\hline II & $1.7 / 2.0$ & $0.8 / 1.0$ & $1.3 / 1.5$ & $1.5 / 1.6$ & $0.8 / 0.8$ & $6.1 / 6.9$ \\
\hline III & $1.6 / 2.0$ & $0.7 / 0.9$ & $1.1 / 1.4$ & $1.5 / 1.7$ & $0.7 / 0.8$ & $5.6 / 6.8$ \\
\hline IV & $2.2 / 2.8$ & $0.8 / 1.0$ & $1.8 / 2.2$ & $2.3 / 2.9$ & $0.8 / 1.0$ & $7.9 / 9.9$ \\
\hline
\end{tabular}




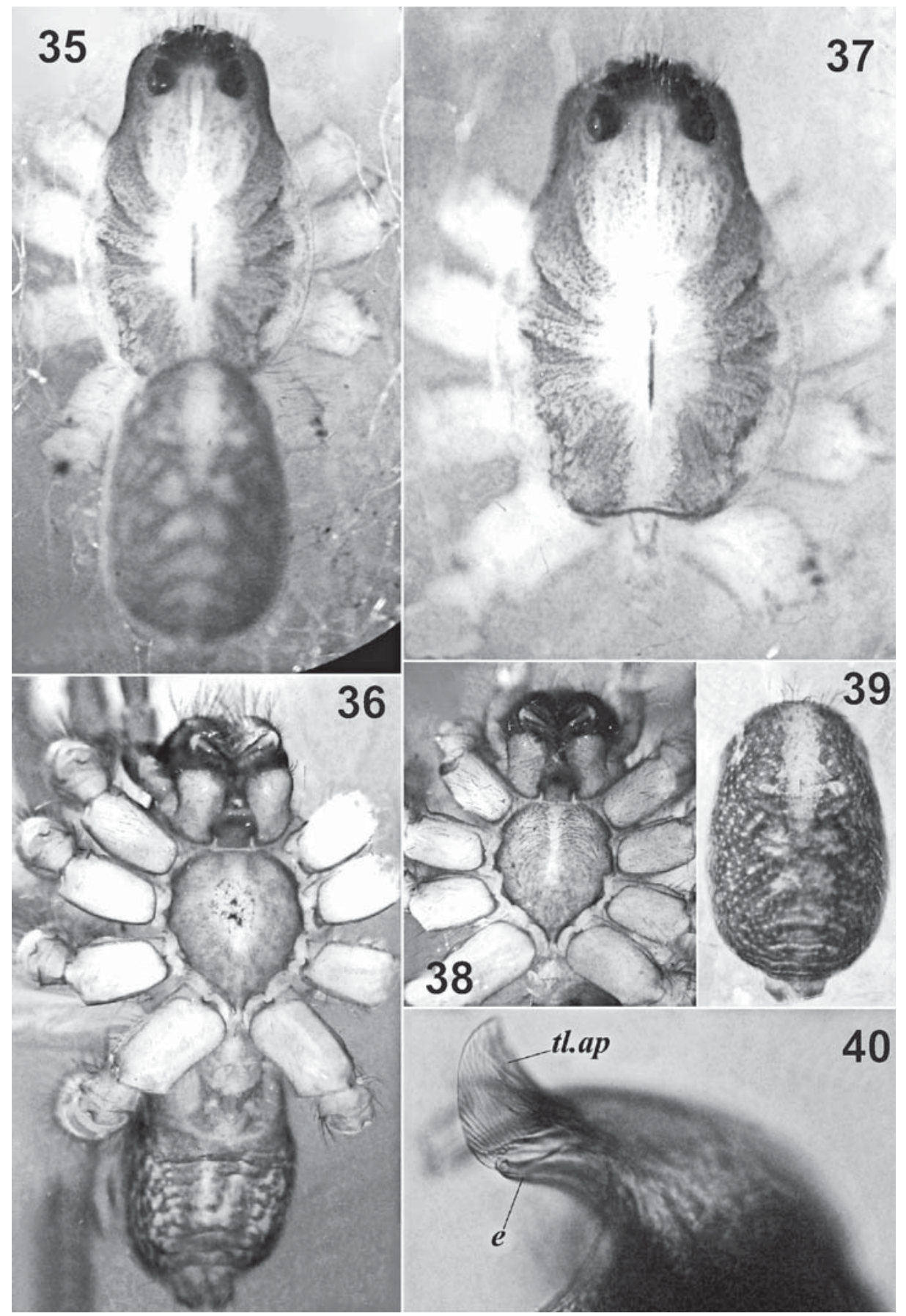

Figs 35-40. Male of Pirata hurkai from Crimea: 35 - general appearance, dorsal view; 36 - general appearance, ventral view; 37 carapace; 38 - sternum; 39 - abdomen, dorsal view; 40 - embolus and terminal apophysis, dorsal view.

Рис. 35-40. Самец Pirata hurkai из Крыма: 35 - внешний вид, дорсально; 36 - внешний вид, вентрально; 37 - карапакс; 38 - стернум; 39 - брюшко, дорсально; 40 - эмболюс и терминальный апофиз, дорсально.

General appearance: male — Figs 65-68; female Figs 72-75. Carapace, sternum, legs and palps brown. Sternum with light stain. Abdomen grey. Carapace and abdomen with dorsal pattern.

Male palp as in Figs 54-62, 69-71 and epigyne as in Figs 63-64, 76-78. Ventral part of tegular apophysis not hidden behind tegulum (Figs 55, 57). Embolus wide. Epigyne with septum (Fig. 63) and with two bent ducts leading to copulatory opening. Size of receptacles variable (Figs 76-77).

VARIATION. Females $(\mathrm{n}=10)$ : total length varies from 5.4 to 6.6 ; carapace length - from 2.6 to 3.2 , carapace width $-2.0-2.3$. 

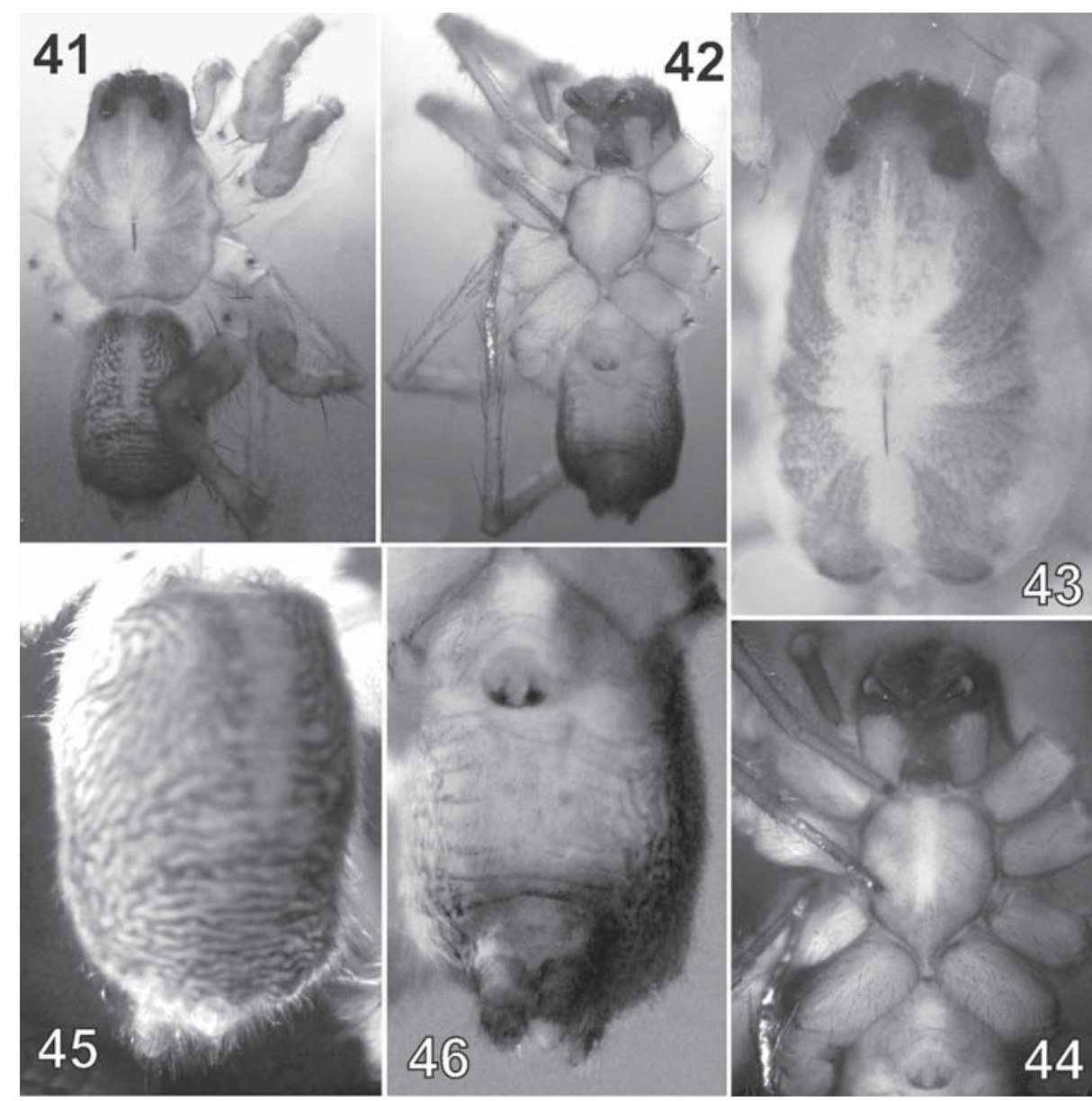

Figs 41-46. Female of Pirata hurkai from Crimea: 41 - general appearance, dorsal view; 42 - general appearance, ventral view; 43 - carapace; 44 - sternum; 45 - abdomen, dorsal view; 46 - abdomen, ventral view.

Рис. 41-46. Самка Pirata hurkai из Крыма: 41 - внешний вид, дорсально; 42 - внешний вид, вентрально; 43 — карапакс; 44 - стернум; 45 - брюшко, дорсально; 46 - брюшко, вентрально.

COCOONS AND FERTILITY. Female with cocoon was taken in Abkhazia in July-August. Diameter of cocoon 2.8. Number of eggs in cocoon 23. Diameter of eggs 0.7. In Czech Republic and Slovakia cocoons of $P$. hygrophilus had about 50 eggs [Miller, 1971].

DISTRIBUTION. West and Central Palaearctic: from Western Europe to Yenisey River, Mongolia and Tuva at the east and from Lapland to Romania and Uzbekistan at the south [Mikhailov, 1997; Marusik et al., 2000; Platnick, 2010].

\section{Pirata latitans (Blackwall, 1841)}

Figs 3, 7, 12, 83-107.

P. l.: Roberts, 1995: 235, f. $\left(\sigma^{7}+\right)$.

P. l.: Guryanova, 2003: 6, f. 14 ()

For a complete list of references see Platnick [2010].

RECORDS FROM CRIMEA. Kovblyuk [2004a].

MATERIAL. UKRAINE, CRIMEA. Alushta Distr.: $1 \sigma^{\gamma}, 2$, 9 (TNU), Ulu-Uzen River, 12.06.2000, G.P.; 1 q, 1 cocoon (TNU), Alaka River, 27.07.2000, G.P. Bakhchisaray Dist.: $2 \sigma^{7} \sigma^{7}, 2$ (TNU-1040/5), Crimean State Nature Reserve, kordon Sosnovyi,
Alma River, 1.07.2001, M.K. Saky Distr., environs Pribrezhnaia railway station: 1 丁', 3 우, 1 cocoon (TNU-1619/12, 1576/10, 1577/5), Salicornia europaea, Halocnemum strobilaceum, pitfalls, 19.05-3.07.2000, M.K.; $28 \sigma^{7} \sigma^{7}, 13$ 우, 1 cocoon (TNU-1679/5, 1680/10, 1681/5, 1682/6, 1683/5, 1684/2, 1685/3), Phragmites, on sand, pitfalls, 19.05-9.08.2000, M.K. Simferopol Distr.: 10 ○ フ7, 6 우, 3 cocoons (TNU-986/7, 987/13, 988/9, 989/13, 990/8, 993/3), Simferopol water reservoir, Zmeinyi Bay, 3.10.19998.10.2000, M.K. Sudak Distr.: 1 (TNU), Voron River, 4.06.2000, G.P. Feodosiya Distr., Karadag Nature Reserve: 3 우 (TNU-2012/ 4), kordon Verhnie trassy, 27-28.07.2004, O.K.; 1 O (TNU-2613/ 3), Karadag valley, 20.05.2008, A.N.; 1 + (TNU-2561/11), BeshTash valley, 22.05.2008, O.K. ABKHAZIA. Ochamchyra Distr.: 1

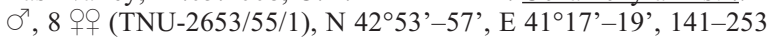
$\mathrm{m}$, environs of Atara-Armyanskaya Vill. and Naa Vill., left bank of Kodor River, bottom of Kodor Mt. ridge, wood with Alnus, Quercus, Fagus, Carpinus, Aesculus, Corylus, Tilia and Rhododendron, glades, 24.07.-04.08.2009, M.K.

DIAGNOSIS. $P$. latitans is similar to $P$. hurkai and $P$. knorri. Differences see in P. hurkai diagnosis.

DESCRIPTION. Male and female from Crimea. Measurements $\left(O^{7} / 9\right)$ : total length 3.7 / 3.6; carapace 2.0 / 1.9 long, 1.5 / 1.4 wide. Length of palp segments (male/female): femur $0.8 / 0.6$, patella $0.4 / 0.3$, tibia 


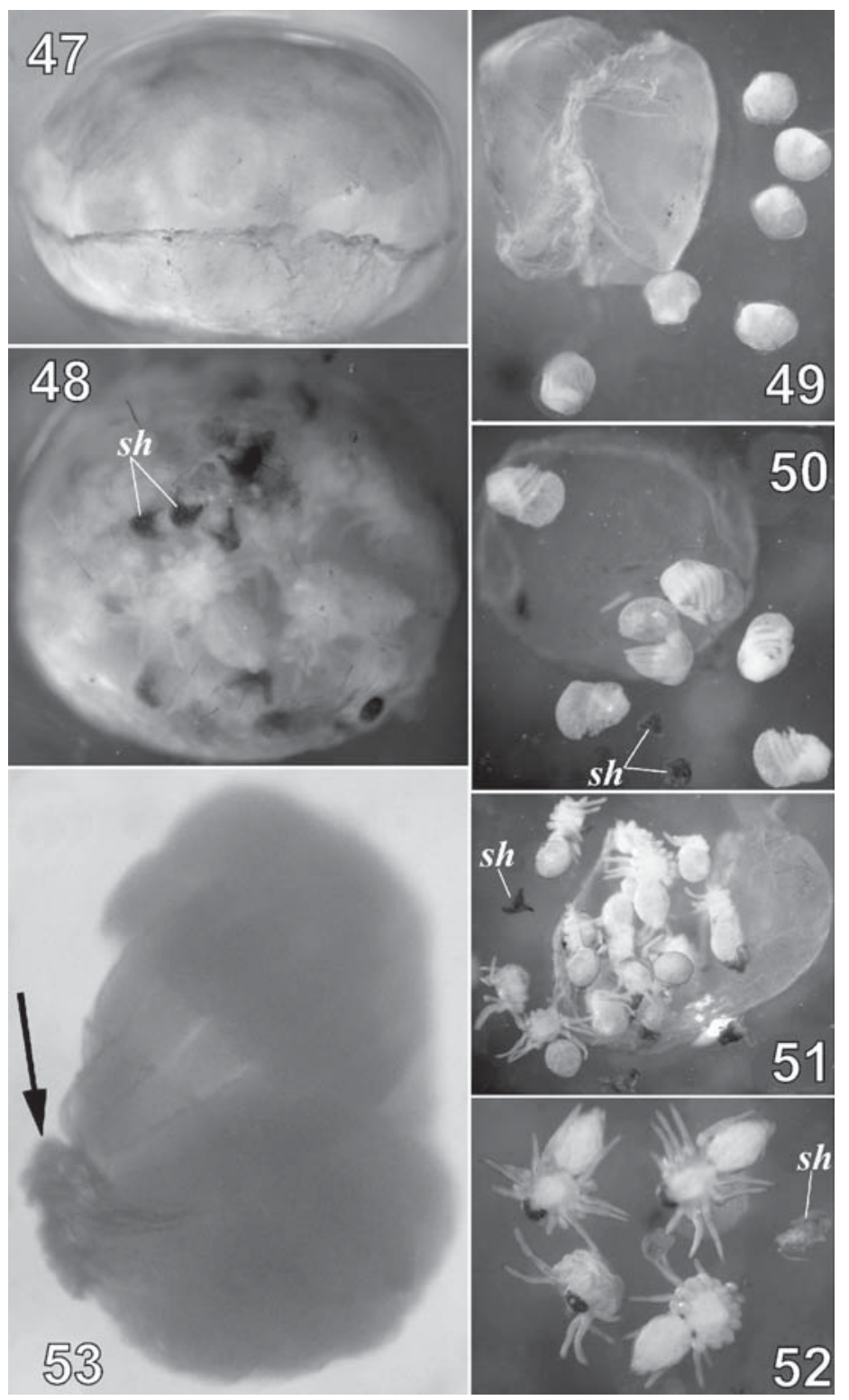

Figs 47-53. Cocoons and early development of Pirata hurkai: 47 - cocoon with eggs, lateral view; 48 - cocoon with first instar nymphs; 49 - eggs; 50 — postembryos; 51 - first instar nymphs without pigment in eyes plate; 52 — first instar nymphs with pigment in eyes plate; 53 - postembryo (the arrow indicates the remained shell, still attached to the posterior tip of abdomen).

Рис. 47-53. Коконы и преимагинальные стадии развития Pirata hurkai: 47 — кокон с яйцами, сбоку; 48 — кокон с нимфами I возраста; 49 - яйца; 50 - постэмбрионы; 51 - нимфы I возраста без пигментированного глазного поля; 52 - нимфы I возраста с пигментированным глазным полем; 53 - постэмбрион (стрелкой показана ещё не сошедшая скорлупа на конце брюшка).

0.4 / 0.4, tarsus $0.6 / 0.6$. Length of leg segments (male/ female):

\begin{tabular}{|c|c|c|c|c|c|c|}
\hline Leg & Femur & Patella & Tibia & Metatarsus & Tarsus & Total \\
\hline I & $1.5 / 1.4$ & $0.6 / 0.6$ & $1.1 / 1.0$ & $1.2 / 1.0$ & $0.7 / 0.6$ & $5.1 / 4.6$ \\
\hline II & $1.4 / 1.2$ & $0.6 / 0.6$ & $1.0 / 0.9$ & $1.2 / 1.0$ & $0.6 / 0.6$ & $4.8 / 4.3$ \\
\hline III & $1.4 / 1.2$ & $0.6 / 0.5$ & $1.0 / 0.9$ & $1.4 / 1.2$ & $0.6 / 0.6$ & $5.0 / 4.4$ \\
\hline IV & $1.8 / 1.8$ & $0.7 / 0.7$ & $1.6 / 1.5$ & $2.2 / 2.0$ & $0.9 / 0.8$ & $7.2 / 6.8$ \\
\hline
\end{tabular}

General appearance: male — Figs 94-97; female Figs 99-103. Carapace, sternum, legs and palps brown. Carapace with pattern characteristic for all Pirata species.
Male palp as in Figs 3, 7, 83-89, 98 and epigyne as in Figs 12, 90-93. Ventral part of tegular apophysis not hidden behind tegulum. In dorsal view, terminal apophysis hidden behind tegular apophysis (Fig. 84). Embolus with peculiar lobe (Fig. 88-89). Epigyne with spherical receptacles.

VARIATION. Males from Crimea $(n=20)$ : total length from 3.3 to 4.0 ; carapace length - from 1.8 to 2.2, carapace width - from 1.3 to 1.6. Females from Crimea $(n=15)$ : total length varies from 3.6 to 5.0 ; carapace length - from 1.9 to 2.2 , carapace width from 1.3 to 1.7 . 

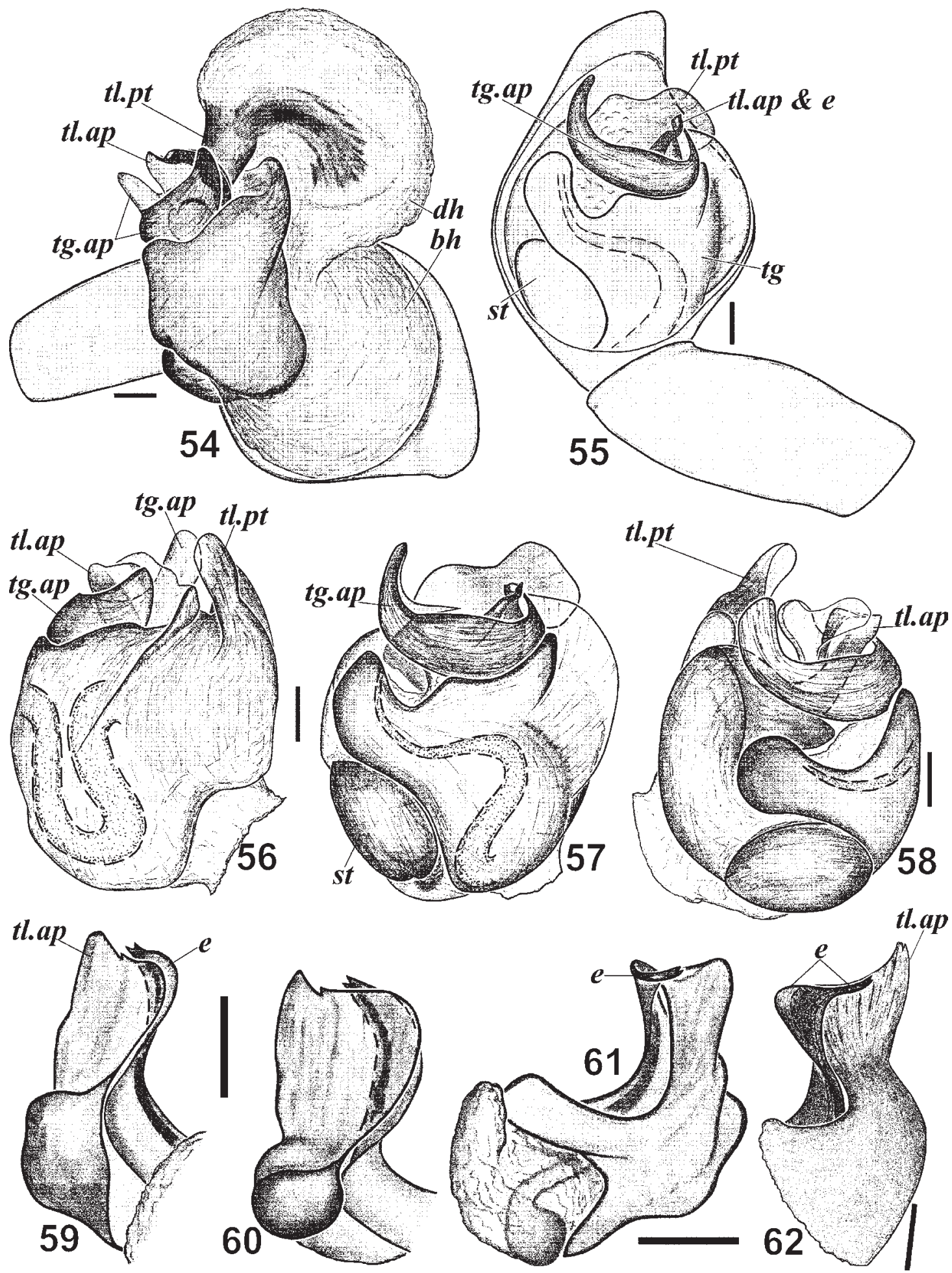

Figs 54-62. Male palp of Pirata hygrophilus from Abkhazia: 54 — expanded male palp, apical view (bulbus — retrolateral view); 55 palp, ventral view; 56 - bulbus, retrolateral view; 57 - bulbus, ventral view; 58 - bulbus, prolateral view; 59 - embolus and terminal apophysis, dorso-retrolateral view; 60 - embolus and terminal apophysis, retrolateral view; 61 - embolus and terminal apophysis, ventro-retrolateral view; 62 - embolus and terminal apophysis, prolateral view.

Рис. 54-62. Пальпа самца Pirata hygrophilus из Абхазии: 54 - пальпа, апикально с вывернутым бульбусом (бульбус ретролатерально); 55 - пальпа, вентрально; 56 - бульбус, ретролатерально; 57 - бульбус, вентрально; 58 - бульбус, пролатерально; 59 - эмболюс и терминальный апофиз, дорсо-ретролатерально; 60 - эмболюс и терминальный апофиз, ретролатерально; 61 - эмболюс и терминальный апофиз, вентро-ретролатерально; 62 - эмболюс и терминальный апофиз, пролатерально. 

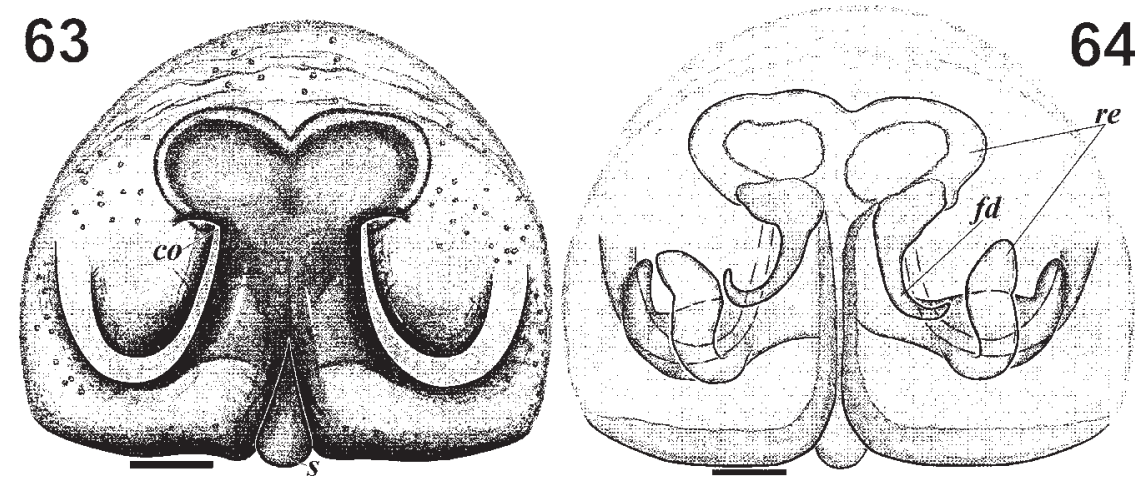

Figs 63-64. Epigyne of Pirata hygrophilus from Abkhazia: 63 - epigyne, ventral view; 64 - epigyne, dorsal view (after maceration).

Рис. 63-64. Эпигина Pirata hygrophilus из Абхазии: 63 - эпигина, вентрально; 64 - эпигина, дорсально (после мацерации).
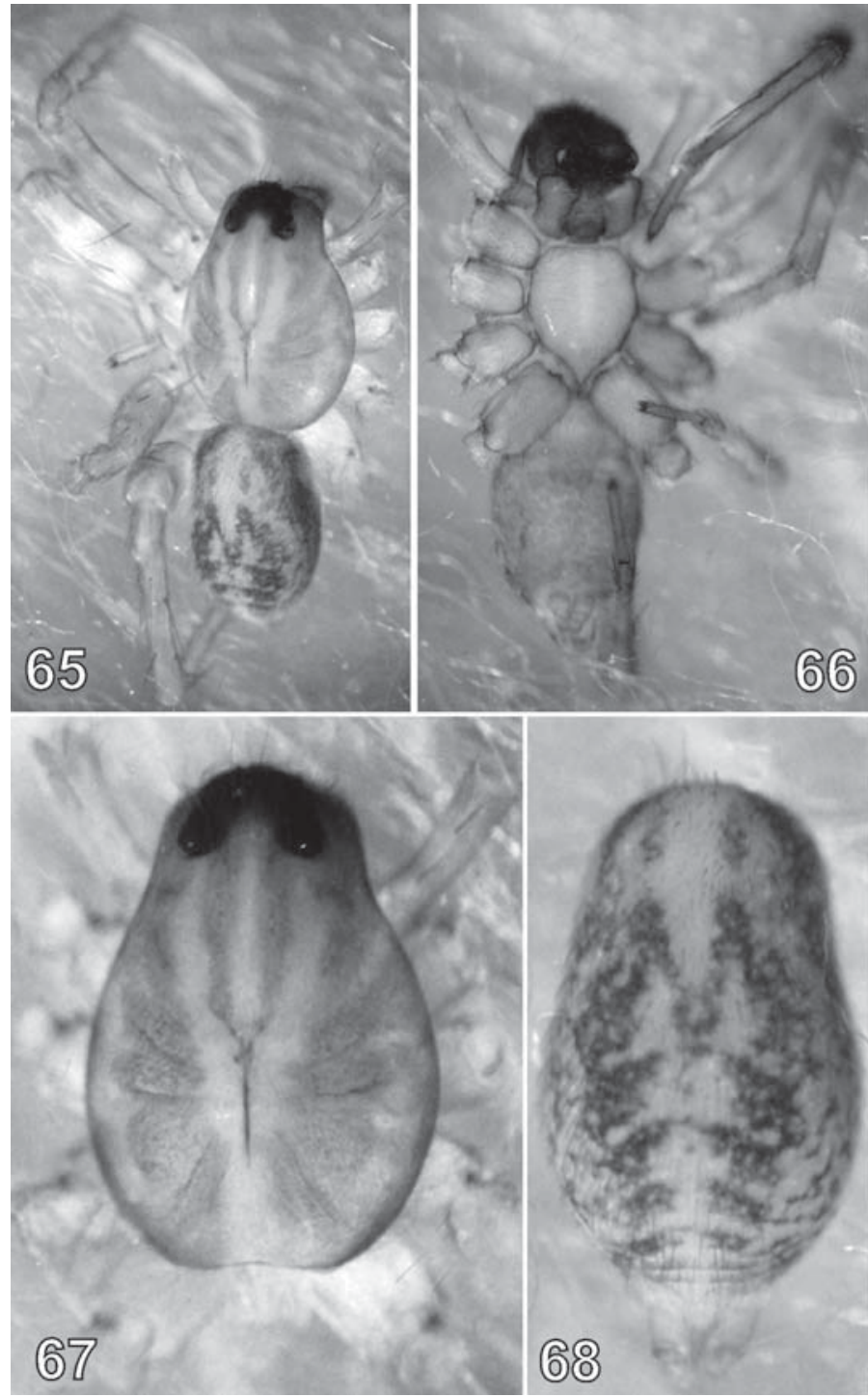

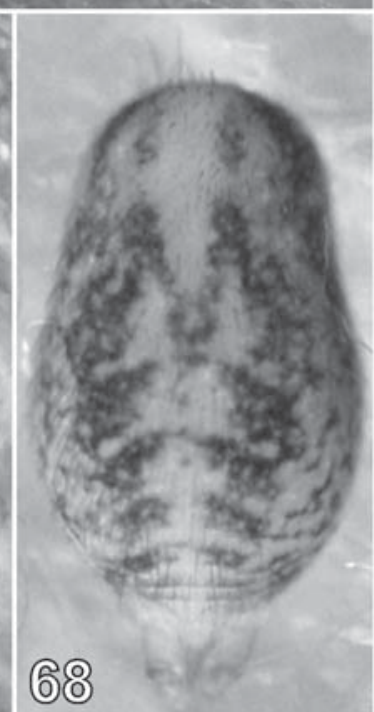

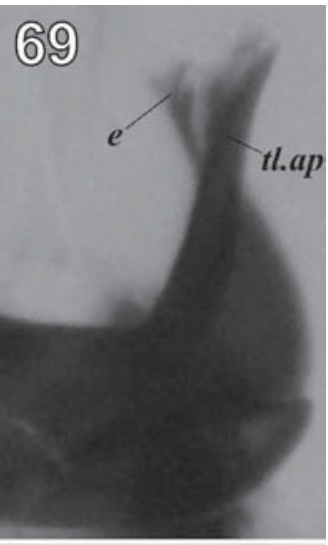
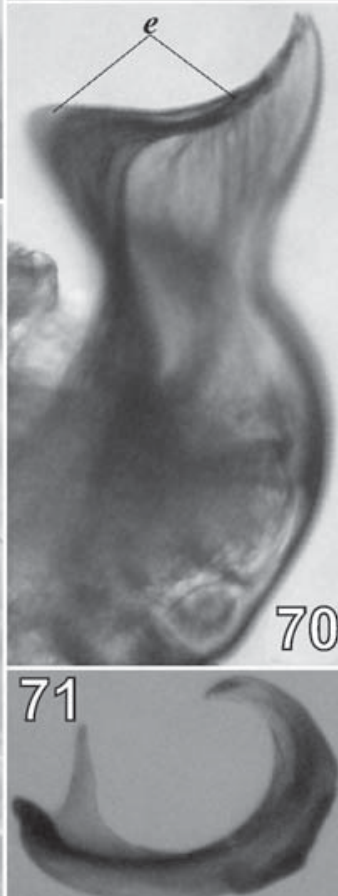

Figs 65-71. Male of Pirata hygrophilus from Abkhazia: 65 - general appearance, dorsal view; 66 - general appearance, ventral view; 67 - carapace; 68 - abdomen, dorsal view; $69-$ embolus and terminal apophysis, ventral view; 70 - embolus and terminal apophysis, prolateral view; 71 - tegular apophysis, apical view.

Рис. 65-71. Самец Pirata hygrophilus из Абхазии: 65 - внешний вид, дорсально; 66 - внешний вид, вентрально; $67-$ карапакс; 68 - брюшко, дорсально; 69 - эмболюс и терминальный апофиз, вентрально; 70 - эмболюс и терминальный апофиз, пролатерально; 71 - тегулярный апофиз, апикально. 

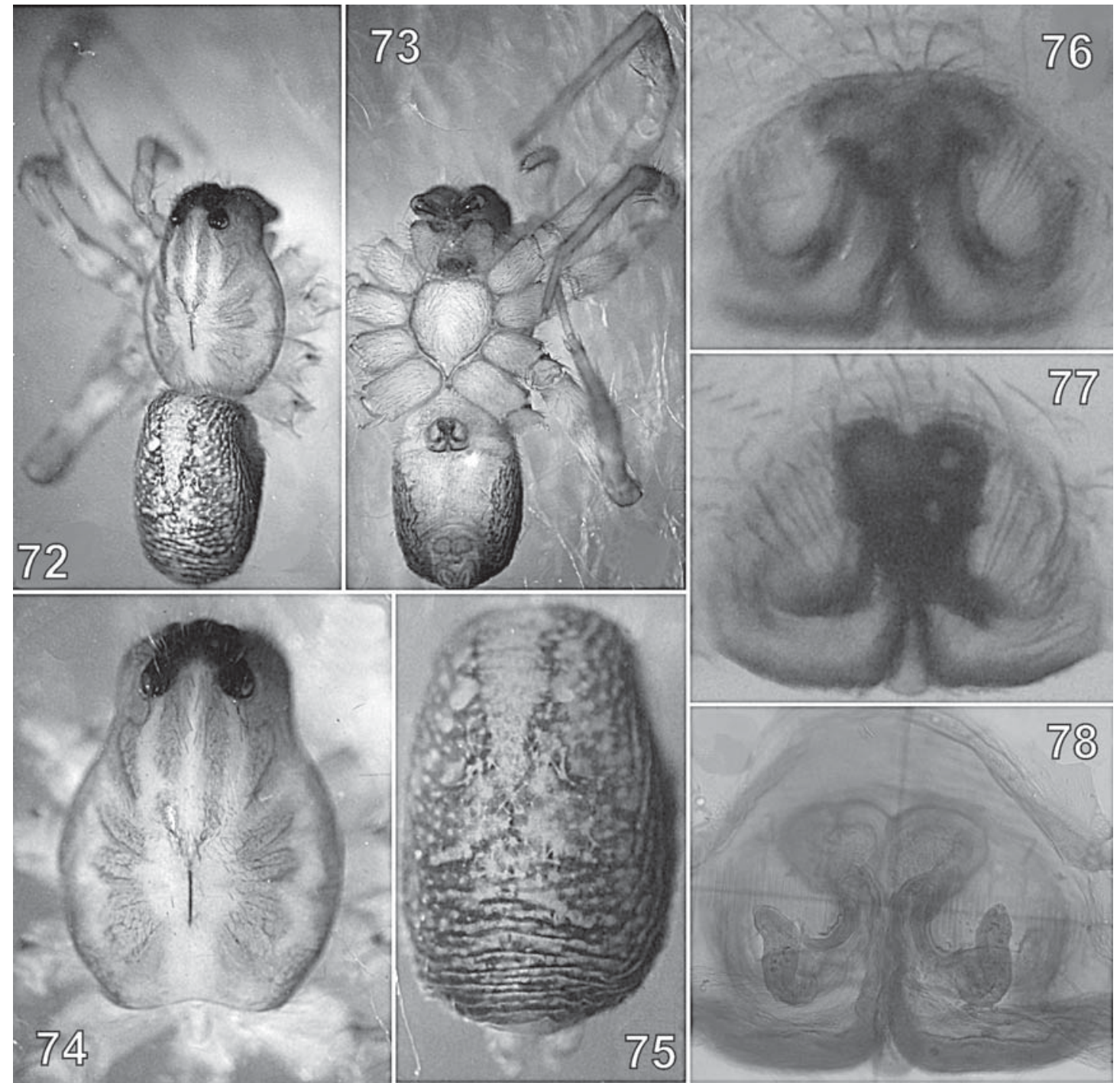

Figs 72-78. Female of Pirata hygrophilus from Abkhazia: 72 - general appearance, dorsal view; 73 - general appearance, ventral view; 74 - carapace; 75 - abdomen, dorsal view; 76-77 — epigyne, ventral view (variations in size of receptacula); 78 - epigyne, dorsal view (after maceration)

Рис. 72-78. Самка Pirata hygrophilus из Абхазии: 72 - внешний вид, дорсально; 73 - внешний вид, вентрально; $74-$ карапакс; 75 - брюшко, дорсально; 76-77 — эпигина, вентрально (вариации размера рецептакул); 78 — эпигина, дорсально (после мацерации).

COCOONS AND FERTILITY. Females with cocoons collected in Crimea in June-July and in October. Diameter of cocoons $(n=5)$ varies from 2.2 to 3.0, height - from 1.8 to 2.5 . One cocoon with nymphs, four cocoons with eggs. Number of eggs in cocoons from 19 to 42, number of nymphs - 19. Diameter of eggs $0.6-0.8$. Total length of nymphs 1.0. Cocoons, eggs and nymphs - Figs 104-107. In Czech Republic and Slovakia cocoons (diameter 2.5-3.0) of P. latitans had 20-40 eggs [Miller, 1971].

DISTRIBUTION. Europe, Anatolia and Caucasus [Buchar, 1966; Fuhn \& Niculescu-Burlacu, 1971; Roberts, 1995; Thaler \& Buchar, 1996; Mikhailov, 1997; Marusik et al., 2003; Blagoev, 2005]. P. latitans is recorded from Abkhazia for the first time.

\section{Pirata piraticus (Clerck, 1757)}

Figs 4, 8, 13-14, 108, 114-116, 124. $\left(O^{\top}+P^{\prime}\right)$

P. p: Michelucci \& Tongiorgi, 1975: 155, f. 3, 5, 7, 9, 11, 13

P. p: Kronestedt, 1980: 65, f. 2A, 3B, D, 4A, 6A-C, 7D-F, $8 \mathrm{E}-\mathrm{F}, 9 \mathrm{C}-\mathrm{D}\left(\mathrm{O}^{\top}+\right)$

P. p: Snazell, 1983: 97, figs. 12-14 (O'P).

For a complete list of references see Platnick [2010].

RECORDS FROM CRIMEA. Spassky [1927], Charitonov [1932]; Mikhailov [1997]; Kovblyuk [2004a].

RECORDS FROM ABKHAZIA. None.

MATERIAL. UKRAINE, CRIMEA. Saky Distr., environs of Pribrezhnaia railway station: 19 (TNU-1655/17), Artemisia steppe, pitfalls, 9-19.05.2000, M.K. ABKHAZIA. Ochamchyra Distr.: 1 \%

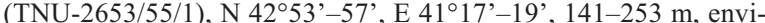
rons of Atara-Armyanskaya Vill. and Naa Vill., left bank of Kodor 


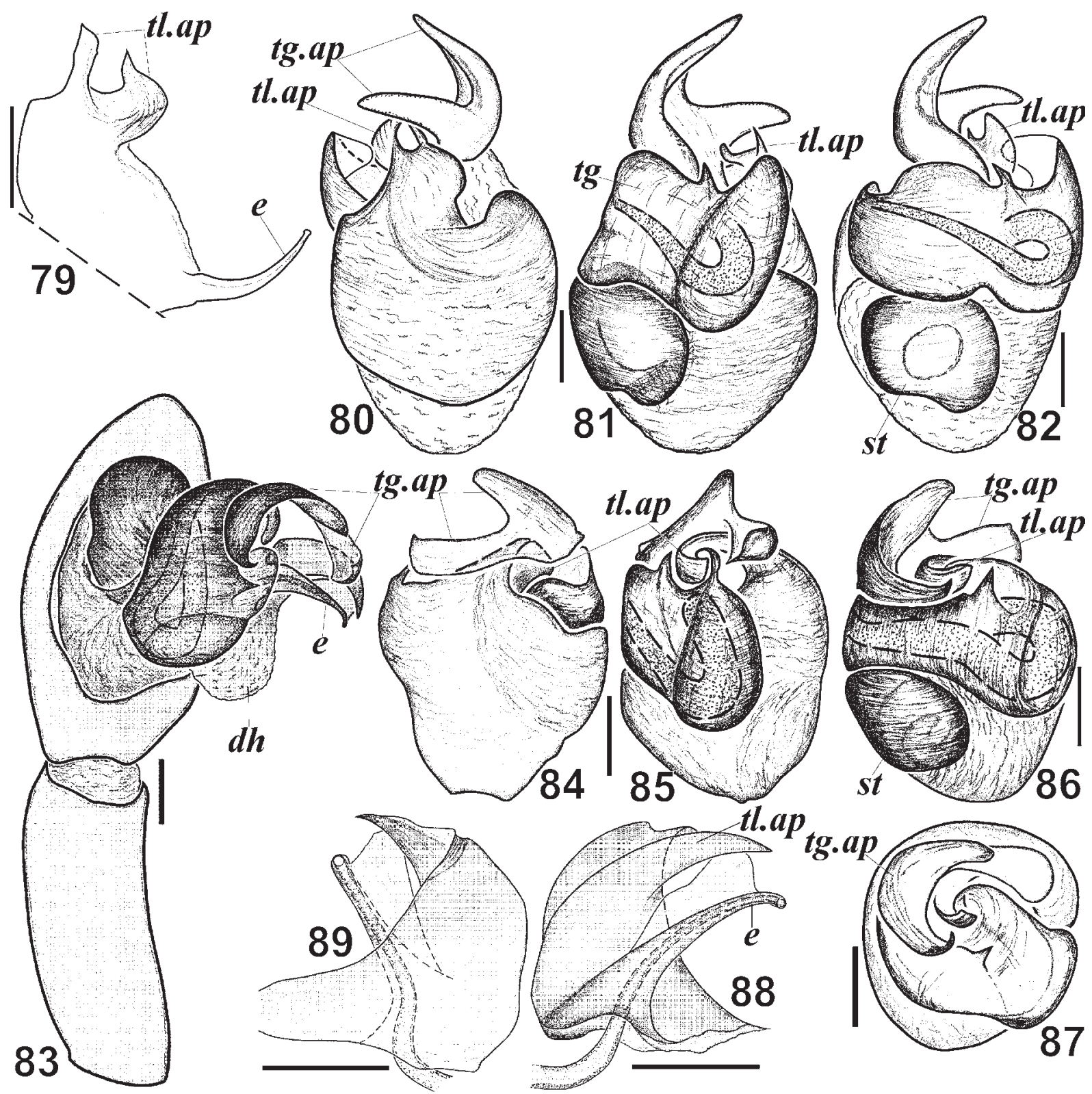

Figs 79-89. Male palp of Pirata knorri (79-82, from Bulgaria) and P. latitans (83-89, from Crimea): 79 - embolus and terminal apophysis, prolateral view; 80,84 - bulbus, dorsal view; 81,85 - bulbus, retrolateral view; 82,86 - bulbus, ventral view; 83 expanded male palp, ventro-prolateral view; 87 - bulbus, apical view; 88 - embolus and terminal apophysis, ventral view; 89 embolus and terminal apophysis, dorsal view.

Рис. 79-89. Пальпа самца Pirata knorri (79-82, из Болгарии) и P. latitans (83-89, из Крыма): 79 - эмболюс и терминальный апофиз, пролатерально; 80, 84 - бульбус, дорсально; 81, 85 - бульбус, ретролатерально; 82, 86 - бульбус, вентрально; 83 пальпа, вентро-пролатерально с вывернутым бульбусом; 87 - бульбус, апикально; 88 - эмболюс и терминальный апофиз, вентрально; 89 - эмболюс и терминальный апофиз, дорсально.

River, bottom of Kodor Mt. ridge, wood with Alnus, Ouercus, Fagus, Carpinus, Aesculus, Corylus, Tilia and Rhododendron, glades, 24.07-04.08.2009, M.K.

COMPARATIVE MATERIAL. BULGARIA. $10^{7}, 1$ (IZS), Devnya TWN (North Black Sea), 17.07.1947, A. Valkanov.

DIAGNOSIS. Holarctic species $P$. piraticus is close to European-Central Asian P. tenuitarsis and East Palaearctic $P$. praedo (Kulczynski, 1885). Three papers directly concerned differences between $P$. piraticus and P. tenuitarsis [Michelucci \& Tongiorgi, 1975; Kronestedt, 1980; Snazell, 1983]. Differences between $P$. tenuitarsis and P. praedo are shown by Logunov [1992: f. 6].

These similar species are difficult to be distinguished from each other: they differ in the shape of tegular apophysis, embolar part of bulbus and the shape of epigyne and receptacles.

Males of $P$. piraticus (Fig. 4) have larger tegular apophysis than those in $P$. tenuitarsis (Fig. 5) and $P$. praedo [Kronestedt, 1980: f. 2 A; Snazell, 1983: f. 12; Tanaka, 1988: f. 3; Logunov, 1992: f. 6]. Base of 

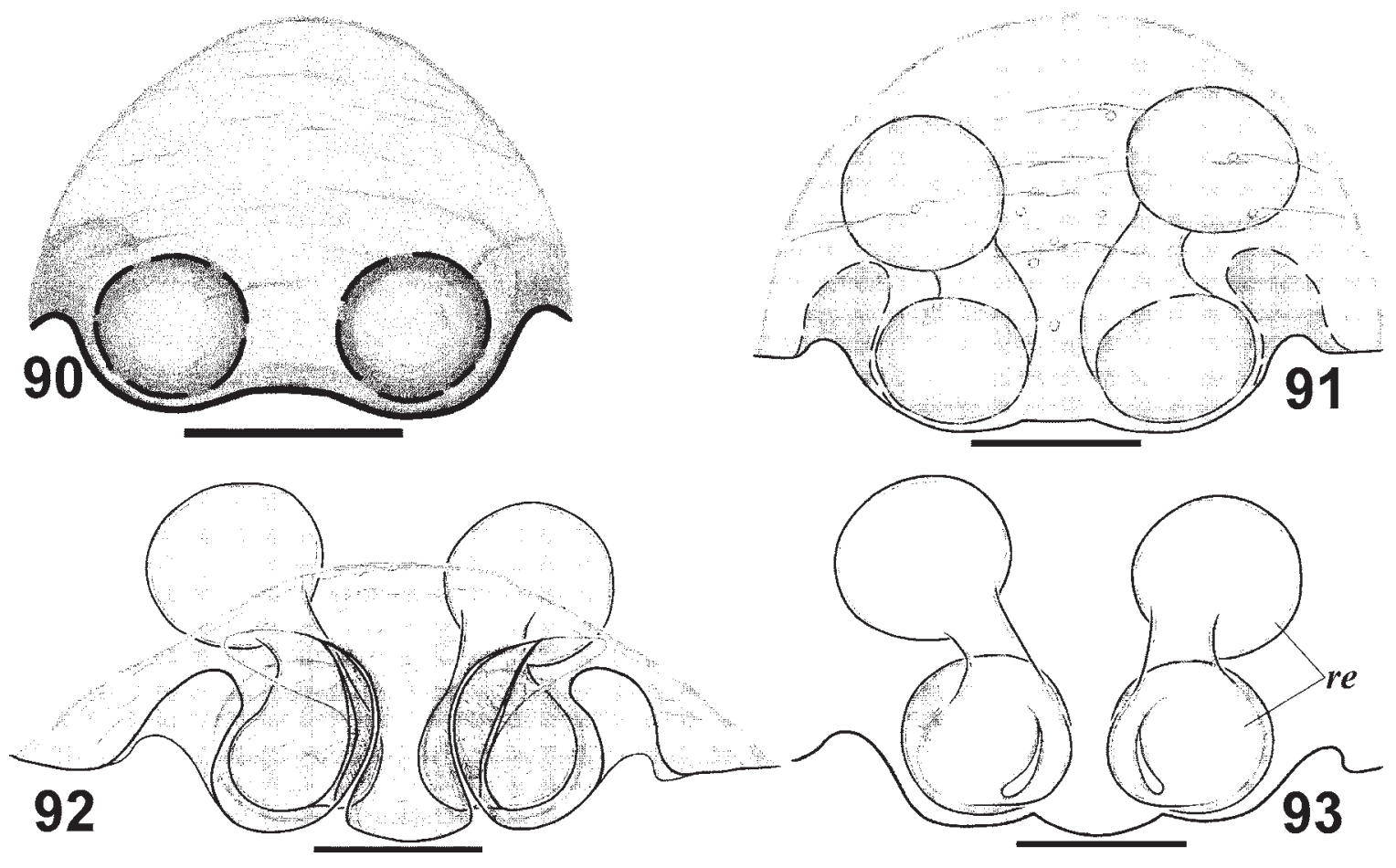

Figs 90-93. Epigyne of Pirata latitans from Crimea: 90 - epigyne, ventral view; 91 - epigyne, ventral view (after maceration); $92-$ 93 - epigyne, dorsal view (after maceration).

Рис. 90-93. Эпигина Pirata latitans из Крыма: 90 - эпигина, вентрально; 91 - эпигина, вентрально (после мацерации); $92-$ 93 - эпигина, дорсально (после мацерации).

tegular apophysis in $P$. tenuitarsis is narrower than that in $P$. praedo [Logunov, 1992: f. 6].

Females of $P$. piraticus are easily distinguished from those of $P$. tenuitarsis by the shape of epigyne and arrangement of receptacles $(P$. piraticus - Figs 114-115, P. tenuitarsis — Fig. 118).

DESCRIPTION. Female from Crimea. Measurements: total length 7.2; carapace 3.2 long, 2.6 wide. Length of palp segments: femur 1.2, patella 0.6 , tibia 0.8 , tarsus 1.0. Length of leg segments:

\begin{tabular}{|c|c|c|c|c|c|c|}
\hline Leg & Femur & Patella & Tibia & Metatarsus & Tarsus & Total \\
\hline I & 2.4 & 1.2 & 2.0 & 2.1 & 0.9 & 8.6 \\
\hline II & 2.3 & 1.2 & 1.7 & 2.0 & 0.8 & 8.0 \\
\hline III & 2.2 & 1.0 & 1.6 & 2.0 & 0.8 & 7.6 \\
\hline IV & 2.9 & 1.2 & 2.6 & 3.2 & 1.1 & 11.0 \\
\hline
\end{tabular}

Male and female from Bulgaria. Measurements $\left(\sigma^{\top}\right)$ +): carapace 3.0 / 3.0 long, 2.3 / 2.3 wide.

General appearance: female - Fig. 124. Carapace, sternum, legs and palps light brown. Abdomen grey with lancet median. Carapace with pattern characteristic for all genus Pirata.

Male palp as in Figs 4, 8, 108 and epigyne as in Figs 13-14, 114-116. Tegular apophysis consists of two parts (Figs 4, 8). Epigyne with peculiar shape of recepatacles.

DISTRIBUTION. Holarctic [Platnick, 2010], Northern India [Marusik, personal communication]. P. piraticus recorded from Abkhazia for the first time.
COMMENTS. All records of $P$. piraticus from Crimea [Charitonov, 1932; Mikhailov, 1997; Kovblyuk, 2004a] are based on one publication [Spassky, 1927]. In our material there is one female from Crimea (environs of Saky), thus occurrence of $P$. piraticus in Crimea is confirmed.

Pirata tenuitarsis Simon, 1876

Figs 5, 9, 15, 109-113, 117-123, 125.

P. moravicus Buchar, 1966: 213-214, f. 3A-C, E-F (D ${ }^{7}+$ ). $\left.\left(\sigma^{\top}+\right)^{P}\right)$

P. $t$.: Michelucci \& Tongiorgi, 1975: 156, f. 1-2, 4, 6, 8, 10, 12

P. $t$ : : Kronestedt, 1980: 67-76, f. 2B, 3A, C, 4B-C, 6D-F, 7AC, 8A-D, 9A-B, 10A ( $\bigcirc^{7}$ ) .

P. t.: Snazell, 1983: 96, f. 9-11 (ठㅇ).

P. t.: Logunov, 1992: 61, f. 6 д-3 (О

P. $t$ : : Roberts, 1995: 233, f. ( $\sigma^{\top}+$ ).

For a complete list of references see Platnick [2010].

RECORDS FROM CRIMEA. Kovblyuk [2007].

MATERIAL. UKRAINE, CRIMEA. Simferopol Distr.: $2 \sigma^{7} \sigma^{7}$, 1 ㅇ (TNU-2208/17), Krasnolesye Vil., 21-30.06.2001, E.S. Feodosiya Distr., Karadag Nature Reserve: $2 \bigcirc^{7} \Im^{7}, 1$ ( 1 (TNU-2012/5), kordon Verhnie trassy, 27-28.07.2004, O.K.

DIAGNOSIS. $P$. tenuitarsis is similar to $P$. piraticus and $P$. praedo. For differences, see $P$. piraticus diagnosis.

DESCRIPTION. Measurements $\left(O^{x} / 7\right)$ : total length 4.8 / 6.4; carapace 2.4 / 3.3 long, 1.6 / 2.6 wide. Length of palp segments (male/female): femur $1.0 / 1.0$, patel- 

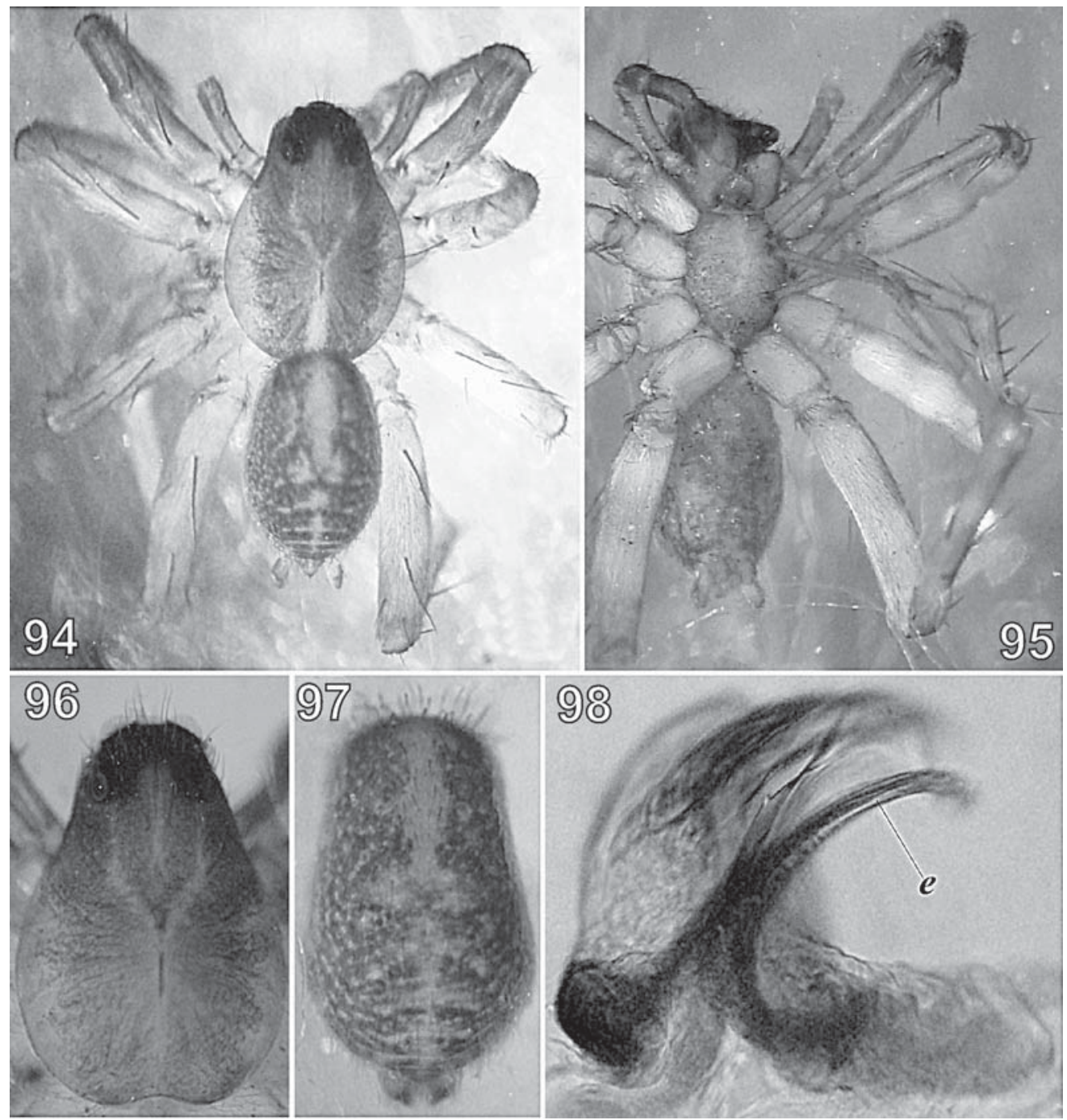

Figs 94-98. Male of Pirata latitans from Crimea: 94 — general appearance, dorsal view; 95 — general appearance, ventral view; 96 - carapace; 97 - abdomen, dorsal view; 98 - embolus and terminal apophysis, ventral view.

Рис. 94-98. Самец Pirata latitans из Крыма: 94 - внешний вид, дорсально; 95 - внешний вид, вентрально; 96 - карапакс; 97 - брюшко, дорсально; 98 - эмболюс и терминальный апофиз, вентрально.

la 0.5 / 0.5, tibia $0.6 / 0.6$, tarsus $0.8 / 0.8$. Length of leg segments (male/female):

\begin{tabular}{|c|c|c|c|c|c|c|}
\hline Leg & Femur & Patella & Tibia & Metatarsus & Tarsus & Total \\
\hline I & $1.9 / 2.2$ & $0.8 / 1.0$ & $1.5 / 1.7$ & $1.8 / 1.9$ & $0.8 / 0.9$ & $6.8 / 7.7$ \\
\hline II & $1.9 / 2.1$ & $0.8 / 1.0$ & $1.3 / 1.5$ & $1.6 / 1.8$ & $0.8 / 0.8$ & $6.4 / 7.2$ \\
\hline III & $1.8 / 2.0$ & $0.8 / 0.8$ & $1.2 / 1.4$ & $1.7 / 1.8$ & $0.8 / 0.8$ & $6.3 / 6.8$ \\
\hline IV & $2.4 / 2.8$ & $0.8 / 1.0$ & $2.0 / 2.4$ & $2.6 / 3.1$ & $1.0 / 1.1$ & $8.8 / 10.4$ \\
\hline
\end{tabular}

General appearance: male - Figs 120-122; female - Fig. 125. Carapace, sternum, legs and palps light brown. Carapace and abdomen with pattern characteristic for Pirata species.

Male palp as in Figs 5, 9, 109-113, 123; epigyne as in Figs 15, 117-119. Tegular apophysis consists of two lobes (Figs 5, 9, 111-113). Embolus thin, without lobe. Epigyne with peculiar shape of recepatacles (Figs 15, 117-119).
VARIATION. Males from Crimea $(n=4)$ : total length from 4.6 to 5.3 ; carapace length - from 2.4 to 2.8 , carapace width - from 1.6 to 2.2. Females from Crimea $(n=2)$ : total length from 3.6 to 5.0 ; carapace length — from 2.8 to 3.3 , carapace width — from 2.0 to 2.6. Specimens from Sweden [Kronestedt, 1980]: carapace length in males $(\mathrm{n}=13) 2.4-2.9$; in females $(\mathrm{n}=21)-2.6-3.4$. Specimens from Czech Republic and Bulgaria: carapace length in males 2.1-3.1; in females - 2.3-3.0 [Buchar, 1966 - as P. moravicus] or 2.8-3.2 [Miller, 1971 — as P. moravicus].

DISTRIBUTION. West and Central Palaearctic: from Portugal to Mongolia and from Sweden to Spain, Italy and Uzbekistan [Michelucci \& Tongiorgi, 1975; Kronestedt, 1980; Logunov, 1992; Roberts, 1995; Thaler \& Buchar, 1996, Mikhailov, 1997; Marusik \& Logunov, 1998; Kovblyuk, 2007]. 

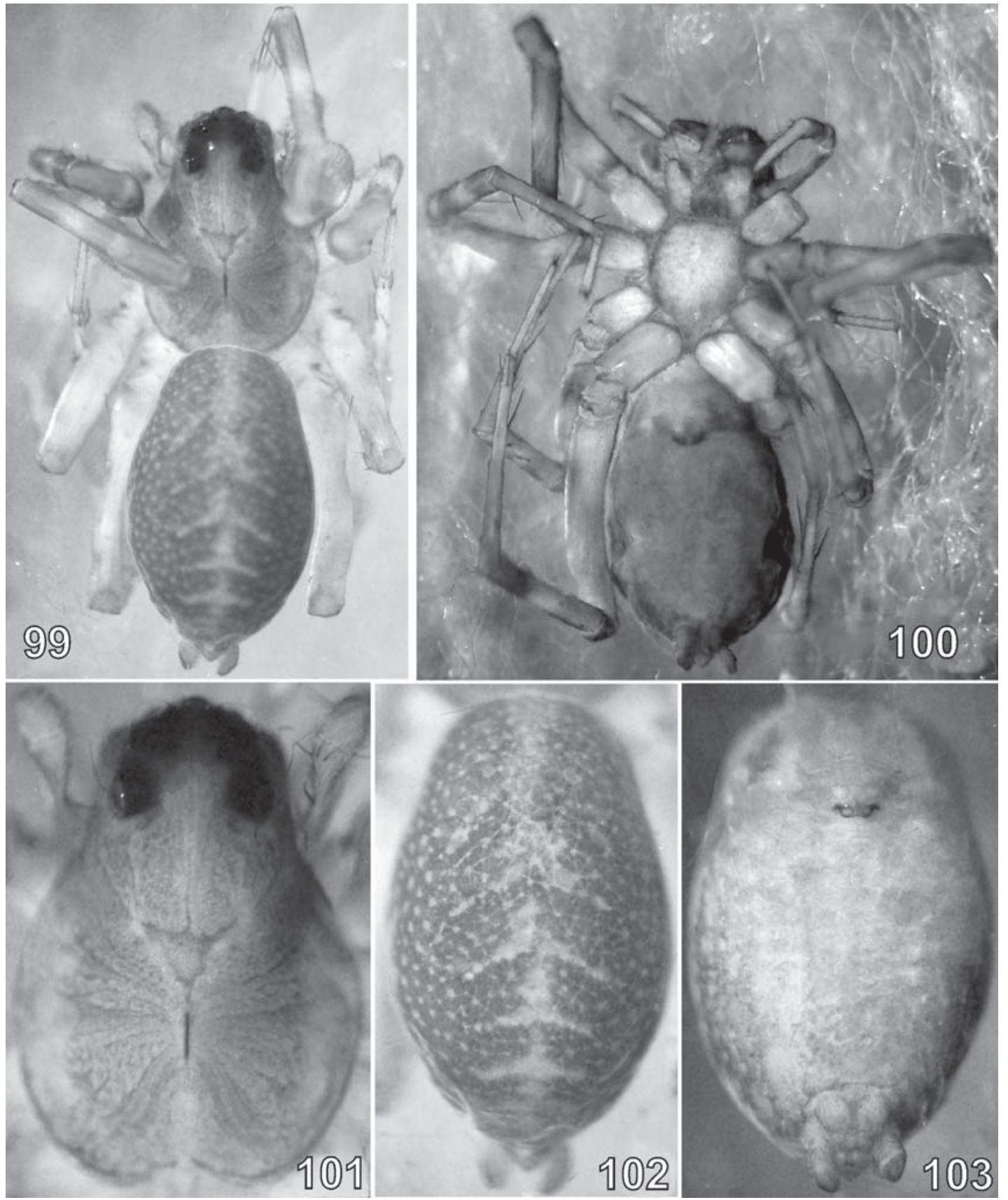

Figs 99-103. Female of Pirata latitans from Crimea: 99 - general appearance, dorsal view; 100 - general appearance, ventral view; 101 - carapace; 102 - abdomen, dorsal view; 103 - abdomen, ventral view.

Рис. 99-103. Самка Pirata latitans из Крыма: 99 - внешний вид, дорсально; 100 - внешний вид, вентрально; 101 карапакс; 102 - брюшко, дорсально; 103 - брюшко, вентрально.

ACKNOWLEDGMENTS. The authors sincerely thank Jan Buchar (Praha, Czech Republic) who confirmed the identification $P$. hurkai from Crimea; Christo Deltshev (Sofia, Bulgaria) for comparative material of $P$. knorri and $P$. piraticus; Gergin Blagoev (Guelph, Canada) for the useful discussion and encouragement. Also we thanks to O.V. Kukushkin (Karadag Nature Reserve), G.A. Prokopov (Simferopol), E.Yu. Sviridenko (Kiev) for providing us some spiders from the Crimea. M.K. provides many thanks to R.S. Dbar (Sukhum, Abkhazia) for a lot of logistic help in expe- ditions in Abkhazia in 2008-2009, and N.N. Yunakov (StPetersburg, Russia), A.A. Khaustov (Yalta, Ukraine), O.S. Bezman-Moseyko and E.G. Sergeeva (both - St-Petersburg, Russia) for the help during the expedition in 2008. Authors sincerely thank Yu.M. Marusik (Magadan, Russia) and A.V. Ponomarev (Rostov-on-Don, Russia) for some useful remarks, comments and corrections, P.E. Gol'din (Simferopol) who improved the English of the earlier draft. English of the final draft was checked by R. Leech (Edmonton, Canada). 

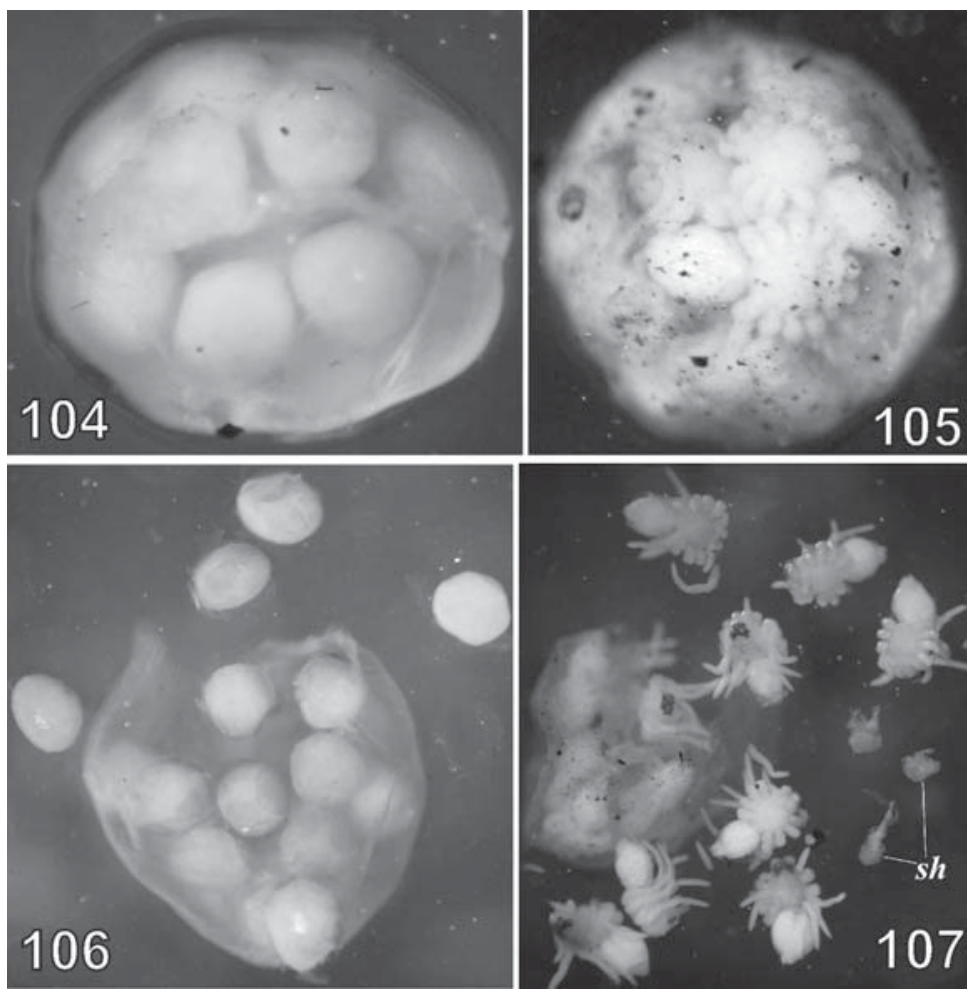

Figs 104-107. Cocoons and early development of Pirata latitans: 104 - cocoon with eggs, lateral view; 105 - cocoon with first instar nymphs; 106 - eggs; 107 - first instar nymphs with pigment in eyes plate.

Рис. 104-107. Коконы и преимагинальные стадии развития Pirata latitans: 104 - кокон с яйцами, сбоку; 105 — кокон с нимфами I возраста; 106 - яйца; 107 - нимфы I возраста с пигментированным глазным полем.

This work of M.K. was supported in part by the Karadag Nature Reserve and Russian Foundation for Basic Research (grant № 09-04-90900 - моб._снг_ст.).

\section{References}

Blagoev G. 2005. A contribution to the knowledge of the wolf spiders (Araneae: Lycosidae) of Albania // Acta zool. Bulg. Vol.57. P.139-144.

Buchar J. 1966. Beitrag zur Kenntnis der paläarktischen PirataArten (Araneae, Lycosidae) // Vestn. csl. Spol. zool. Vol.30. No.3. P.210-218.

Charitonov D.E. 1932. Katalog der russischen Spinnen. AN SSSR. Leningrad: Izdatelstvo AN SSSR. 206 p.

Downes M.F. 1987. A proposal for standardization of the terms used to describe the early development of spiders, based on a study of Theridion rufipes Lucas (Araneae: Theridiidae) // Bull. Brit. arachnol. Soc. Vol.7. No.6. P.187-193.

Guryanova V.E. 2003. [Materials to the spider fauna Podolian Wood-and-Steppe (Ukraine)] // Vestnik zoologii. Vol.37. No.5. P.3-11 [in Russian].

Guseinov E.F. 1999. [Landscape-zonal distribution of spiders (Arachnida, Aranei) of Lenkoran Natural Region of Azerbaijan] // Dokl. AN Azerb. Vol.54. No.3-4. P.109-114 [in Russian].

Fuhn I.E., Niculescu-Burlacu F. 1971. Arachnida. Fam. Lycosidae // Fauna Republicii Socialiste Romania. Vol.5. No.3. 256 p.

Harvey P.R., Nellist D.R., Telfer M.G. (eds.) 2002. Provisional atlas of British spiders (Arachnida, Araneae). Vol. 1-2 / Huntington: Biological Records Centre. 406 p.

Heimer S., Nentwig W. 1991. Spinnen Mitteleuropas: ein Bestimmungsbuch. Berlin; Hamburg: Parey. 543 S.

Kovblyuk N.M. 2002. Records of Caucasian spider species in the Crimea (Arachnida, Araneae) // Program, abstracts, list of participants of the $20^{\text {th }}$ European Colloquium of Arachnology (22-26 July 2002, Szombathely, Hungary). Szombathely: Balogh es Tarsa Nyomda. P.71.

Kovblyuk N.M. 2004a. [Catalogue of the spiders (Arachnida, Aranei) of the Crimea] // Voprosy razvitiya Kryma. Vyp.15. Problemy inventarizatsii krymskoi bioty. Simferopol: Tavriya-Plus. P.211-262 [in Russian].

Kovblyuk M.M. 2004b. A survey of spider species with CrimeoCaucasian disjunct ranges (Arachnida, Araneae) // F. Samu \& C. Szinetar (eds.). European Arachnology 2002. Proceedings of the 20th European Colloquium of Arachnology (Szombath1y, 22-26 July 2002). Budapest: Plant Protection Institute \& Berzsenyi College. P.251-258.

Kovblyuk M.M. 2007. [New data about spiders (Aranei) of the Crimea] // Zamotailov A.S. (ed.). Problemy i perspektivy obshchei entomologii. Tezisy dokladov 13-go S'ezda Russkogo Entomologicheskogo obshchestva, Krasnodar, 9-15 sentyabrya 2007. Krasnodar. P.152-153 [in Russian].

Kovblyuk M.M., Marusik Yu.M., Ponomarev A.V., Gnelitsa V.A., Nadolny A.A. 2011. Spiders (Arachnida: Aranei) of Abkhazia // Arthropoda Selecta. Vol.20. No.1. P.21-56.

Kronestedt T. 1980. Comparison between Pirata tenuitarsis Simon, new to Sweden and England, and P. piraticus (Clerck), with notes on taxonomic characters in male Pirata (Araneae: Lycosidae) // Entomologica Scand. Vol.11. P.65-77.

Logunov D.V. 1992. [To the spider fauna of the Bolshekhekhtsyrski State Reserva (Khabarovsk Province). I. Families Araneidae, Lycosidae, Philodromidae, Tetragnathidae and Thomisidae] // Sib. Biol. Zhurn. Vol.4. P.56-68 [in Russian].

Logunov D. 1998. Pseudeuophrys is a valid genus of the jumping spiders (Araneae, Salticidae) // Revue Arachnologique. T.12. Fasc.11. P.109-128.

Marusik Yu.M., Guseinov E.F., Koponen S. 2003. Spiders (Arachnida: Aranei) of Azerbaijan. 2. Critical survey of wolf spiders 


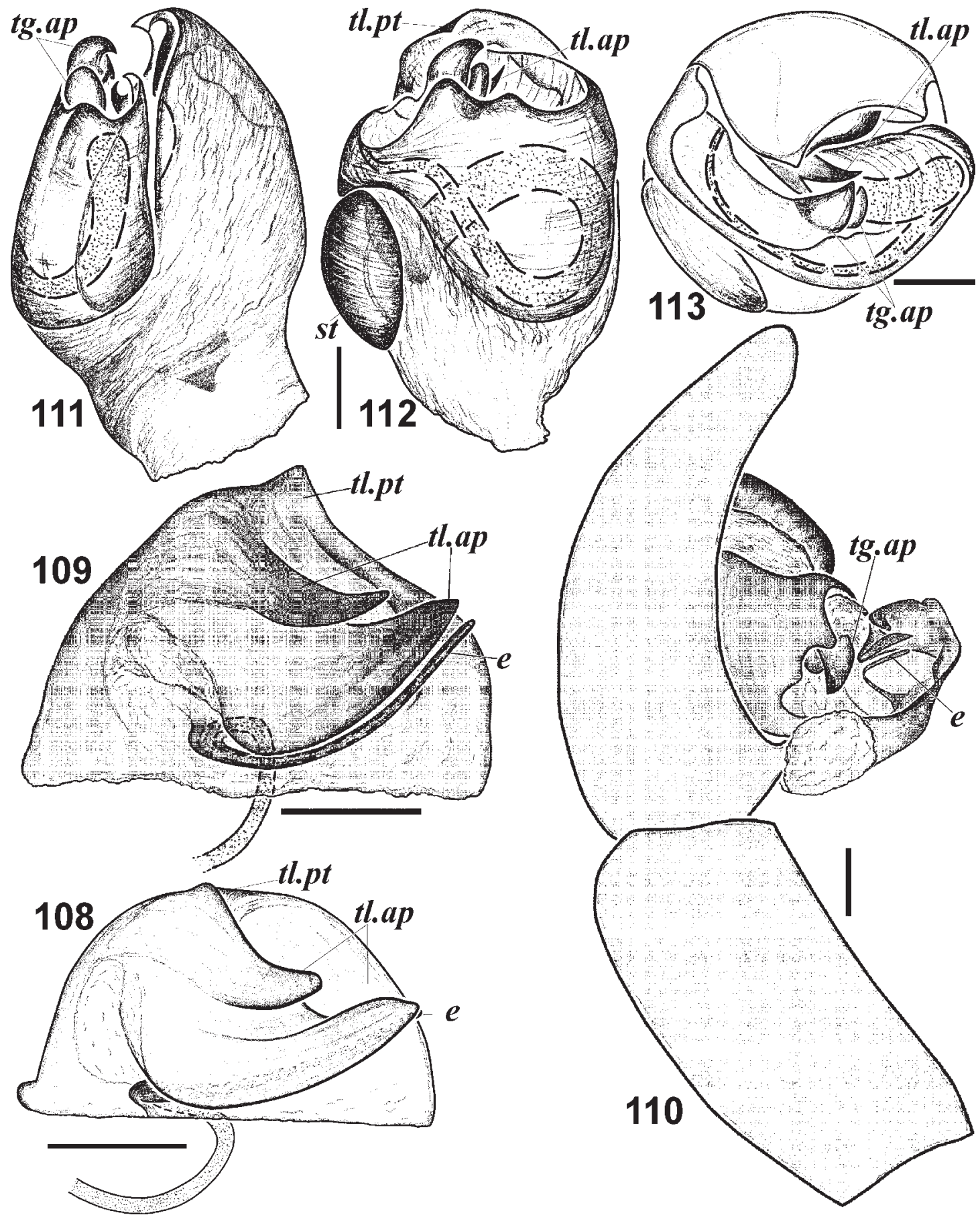

Figs 108-113. Male copulatory organs of Pirata piraticus (108, from Bulgaria) and P. tenuitarsis (109-113, from Crimea): 108109 - embolus and terminal apophysis, ventral view; 110 — expanded palp, prolateral view; 111 — bulbus, retrolateral view; 112 bulbus, ventral view; 113 - bulbus, apical view.

Рис. 108-113. Копулятивные органы самцов Pirata piraticus (108, из Болгарии) и P. tenuitarsis (109-113, из Крыма): 108109 - эмболюс и терминальный апофиз, вентрально; 110 - пальпа самца, пролатерально с вывернутым бульбусом; 111 бульбус, ретролатерально; 112 - бульбус, вентрально; 113 - бульбус, апикально.

(Lycosidae) found in the country with description of three new species and brief review of Palaearctic Evippa Simon, 1885 // Arthropoda Selecta. Vol.12. No.1. P.47-65.

Marusik Yu.M., Logunov D.V. 1998. On the spiders (Aranei) collected in central Mongolia during a joint American-Mongolian-Russian expedition in 1997 // Arthropoda Selecta. Vol.7.
No.3. P.233-254

Marusik Yu.M., Logunov D.V., Koponen S. 2000. Spiders of Tuva, South Siberia. Magadan: IBPN FEB RAS. 252 p.

Mcheidze T.S. 1997. [Spiders of Georgia: Systematics, Ecology, Zoogeographic Review]. Tbilisi University. 390 p. [in Georgian]. 

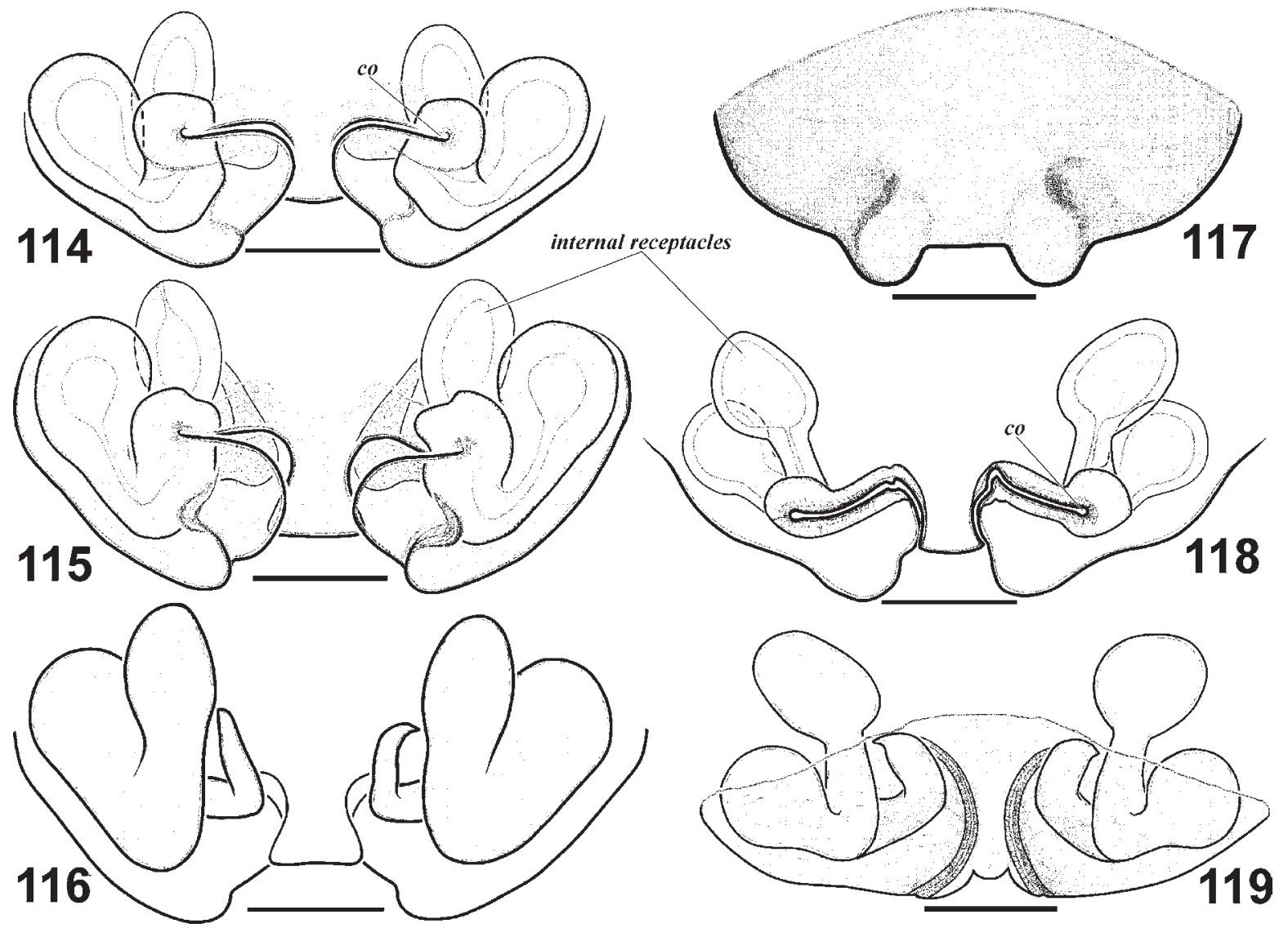

Figs 114-119. Epigynes of Pirata piraticus (114 — from Crimea; 115-116 — from Bulgaria) and P. tenuitarsis (117-119 - from Crimea): 114-115, 118 - ventral view (after maceration); 117 — ventral view; 116, 119 — dorsal view (after maceration).

Рис. 114-119. Эпигины Pirata piraticus (114 - из Крыма; 115-116 - из Болгарии) и P. tenuitarsis (117-119 - из Крыма): 114-115, 118 - вентрально (после мацерации); 117 - вентрально; 116, 119 - дорсально (после мацерации).

Michelucci R., Tongiorgi P. 1975. Pirata tenuitarsus Simon (Araneae, Lycosidae): a widespread but long-ignored species // Bull. Br. arachnol. Soc. Vol.3. Pt.6. P.155-158.

Mikhailov K.G. 1997. Catalogue of the spiders (Arachnida, Aranei) of the territories of the former Soviet Union. Moscow: Zoological Museum of the Moscow State University. $416 \mathrm{p}$.

Mikhailov K.G. 1998. Catalogue of the spiders (Arachnida, Aranei) of the territories of the former Soviet Union. Addendum 1. Moscow: KMK Scientific Press Ltd. 50 p.

Miller F. 1971. Pavouci-Araneida // Klíč zvířeny ČSSR. Praha: Československá Akademie Věd. Díl 4. P.51-306.

Ovtsharenko V.I. 1979. [Spiders of the families Gnaphosidae, Thomisidae, Lycosidae (Aranei) in the Great Caucasus] // Trudy Zool. Inst. AN SSSR. Vol.85. P.39-53 [in Russian].

Platnick N.I. 2010. The world spider catalog, version 10.5. American Museum of Natural History, online at http://research.amnh org/entomology/spiders/catalog/index.html

Polchaninova N.Yu., Prokopenko E.V. 2007. A checklist of the spider fauna (Araneae) of the "Svyati Gory" National Nature Park (Ukraine, Donetsk Region) // Arthropoda Selecta. Vol.16. No.3. P.177-189.

Ponomarev A.V., Polchaninova N.Yu. 2006. [Materials to the spider fauna (Aranei) Belgorod Region] // Caucasian entomological bulletin. Vol.2. No2. P.143-164 [in Russian].

Ponomarev A.V., Mikhailov K.G. 2007. [Addition to fauna of spiders (Aranei) of the Russian Caucasus] // Bioraznoobrazie i transformatsiya gornykh ekosistem Kavkaza. Trudy Yuzhnogo nauchnogo tsentra RAN. Rostov-na-Donu: YuNTs RAN Publ. No.3. P.130-151.

Ponomarev A.V., Khalidov A.Kh., Aliev M.A. 2008. [Addition to fauna of spiders (Aranei) of the Dagestan] // Izvestiya Dagestanskogo gos. ped. univers. Estestvenie i tochnie nauky. Vol.3. P.60-71 [in Russian].

Roberts M.J. 1995. Spider of Britain and Northern Europe. London: Harper Collins Publishers. 383 p.

Snazell R. 1983. On two spiders recently recorded from Britain // Bull. Br. arachnol. Soc. Vol.6. Pt.3. P.93-98.

Spassky S.A. 1927. [Materials to the spider fauna of the Tauric Gouvernement] // Izvestiya Donskogo Instituta selskogo khozyaistva i melioratsii. Vol.7. P.66-80 [in Russian].

Tanaka H. 1986. A new species of the genus Pirata Sundevall (Araneae: Lycosidae) from Japan // Proceeding of the Japanese Society of Systematic Zoology. Vol.33. P.19-22.

Tanaka H. 1988. Lycosid spiders of Japan. I. The genus Pirata Sundevall // Acta Arachnologica. Vol.36. No.1. P.33-77.

Thaler K., Buchar J. 1996. Die Wolfspinnen von Österreich 3. Gattungen Aulonia, Pardosa (p.p.), Pirata, Xerolycosa (Arachnida, Araneae: Lycosidae). Faunistisch-tiergeographische Ubersicht // Carinthia II. 186/106. S.393-410.

Responsible editor Yu.M. Marusik 

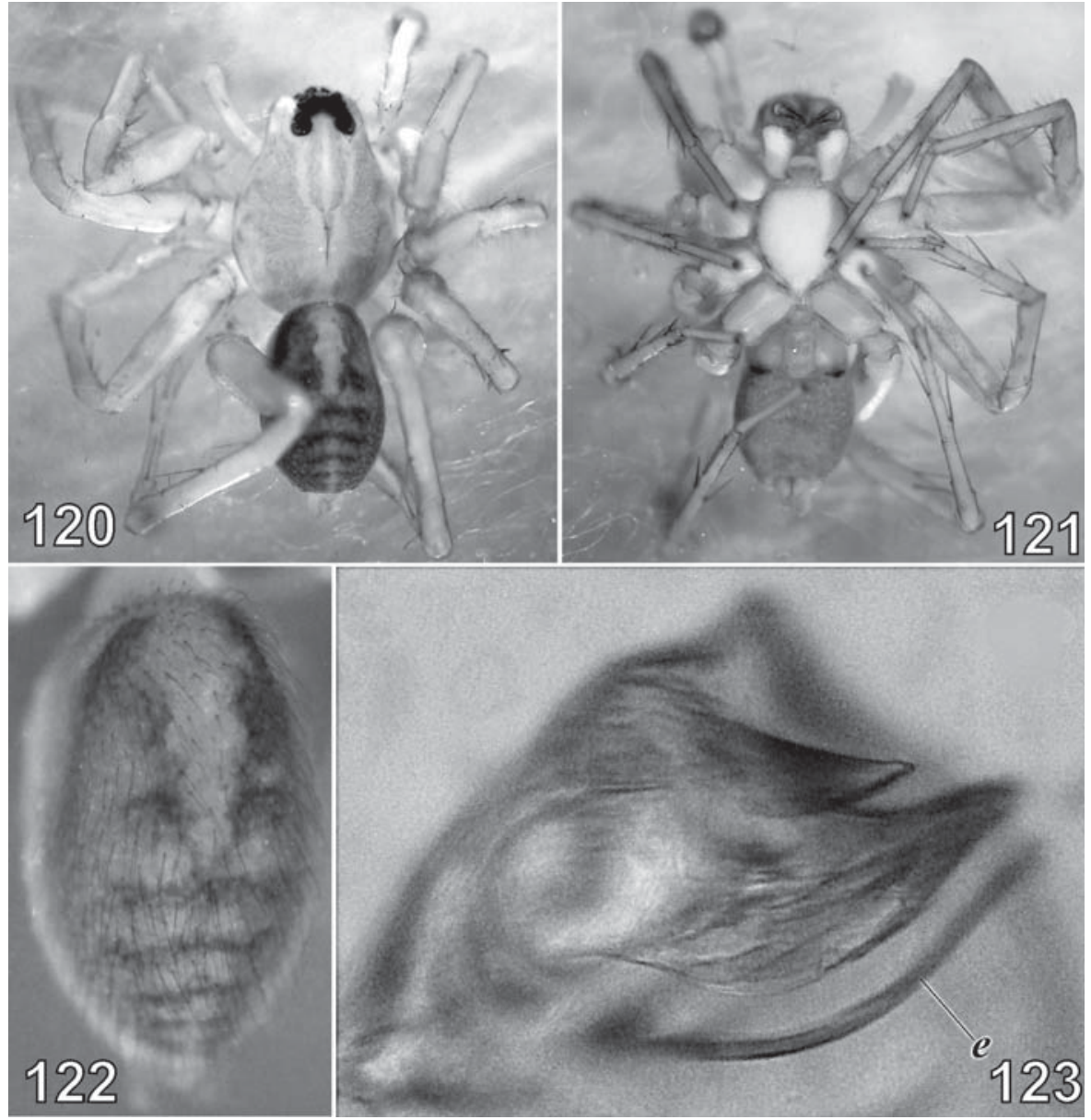

Figs 120-123. Male of Pirata tenuitarsis from Crimea: 120 - general appearance, dorsal view; 121 - general appearance, ventral view; 122 - abdomen, dorsal view; 123 - embolus and terminal apophysis, ventral view.

Рис. 120-123. Самец Pirata tenuitarsis из Крыма: 120 - внешний вид, дорсально; 121 - внешний вид, вентрально; $122-$ брюшко, дорсально; 123 — эмболюс и терминальный апофиз, вентрально.
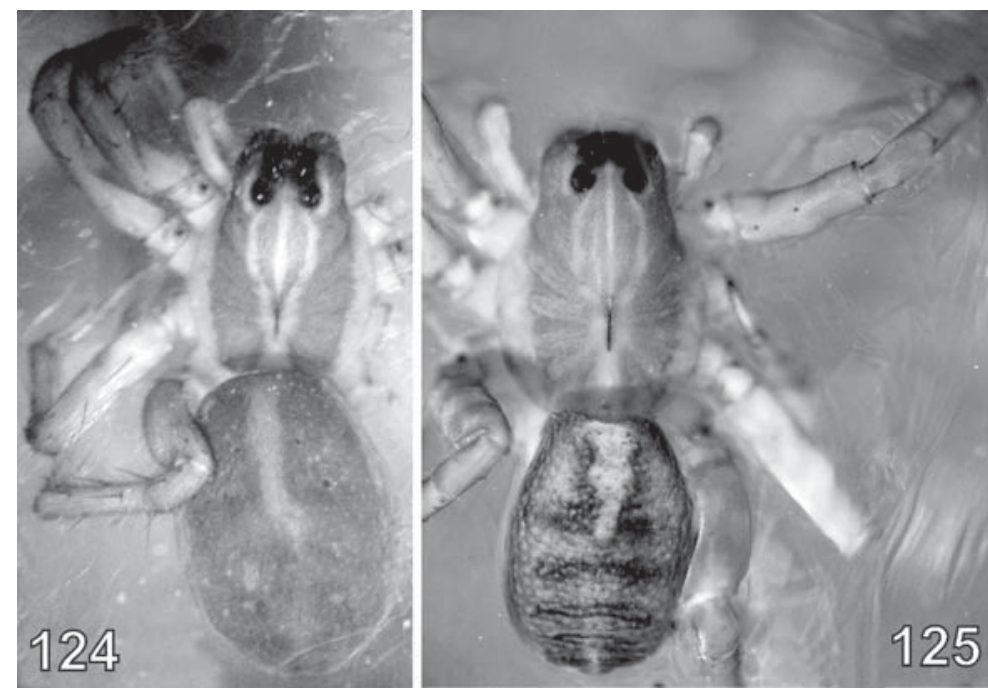

Figs 124-125. General appearance of Pirata piraticus (124) and P. tenuitarsis (125) females from Crimea, dorsal view. Рис. 124-125. Внешний вид самок Pirata piraticus (124) и P. tenuitarsis (125) из Крыма, дорсально. 